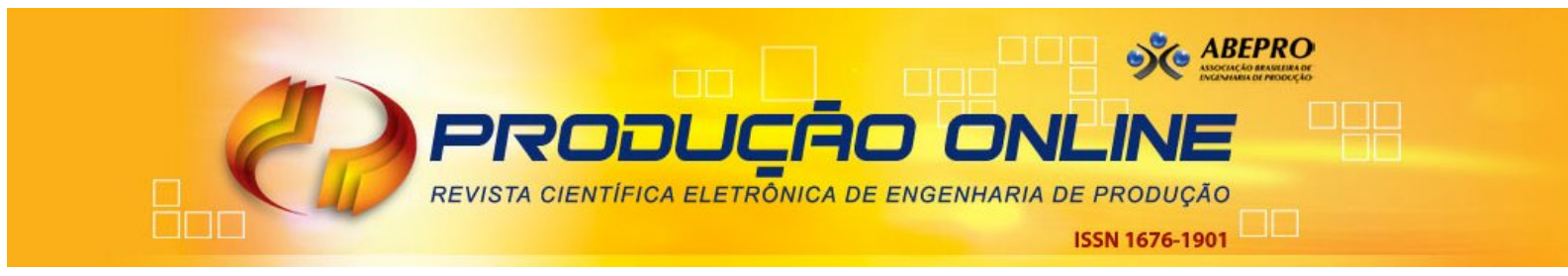

\title{
ESTUDO COMPARATIVO DA USABILIDADE DE COMANDOS DIRECIONAIS PARA DUAS CONCEPÇÕES DE MÁQUINAS AGRÍCOLAS
}

\section{COMPARATIVE STUDY OF THE USABILITY OF DIRECTIONAL COMMANDS FOR TWO DIFFERENT CONCEPTIONS OF AGRICULTURAL MACHINERY}

\author{
Ricardo Kozoroski Veiga* E-mail: ricardokveiga@bol.com.br \\ Eugenio Andrés Díaz Merino* E-mail: eugenio.merino@ufsc.br \\ Leila Amaral Gontijo* E-mail: leila.gontijo@ufsc.br \\ Fabrício Campos Masiero* E-mail: masiero@ifc-riodosul.edu.br \\ Giselle Schmidt Alves Díaz Merino*E-mail: gisellemerino@gmail.com \\ *Universidade Federal de Santa Catarina (UFSC), Florianópolis, SC
}

\begin{abstract}
Resumo: O estado de Santa Catarina apresentou um expressivo crescimento em sua frota de máquinas agrícolas nos últimos 40 anos. Pelas origens históricas, o estado experimentou uma agricultura familiar forte que se desenvolveu em pequenas propriedades. Essa reduzida dimensão das propriedades rurais impulsionou a aquisição de máquinas agrícolas de pequeno porte tais como os motocultivadores. Estima-se que em Santa Catarina existam mais de 20 mil máquinas dessa natureza. Pela concepção inicial dessa máquina seu emprego destina-se a operações com deslocamento em pé, possuindo para isso comandos dimensionados para a postura na vertical. Porém grande parcela dos motocultivadores é empregada no transporte de carga e pessoal, através da adaptação de um implemento que possibilita a condução na posição sentada. Essa modificação é incompleta, pois não possibilita a instalação de volante para manobras. Assim essa inadequação do comando aumenta a dificuldade na condução do veículo e pode potencializar o erro humano, levando ao acidente. Buscando comparar a usabilidade e o índice de erros no acionamento de comandos de motocultivadores e de tratores, no trabalho utilizou-se de dois métodos: análise pelo modelo UsaDesign (U-D® )e teste de usabilidade. Um painel posicionado à frente das duas máquinas agrícolas simulou obstáculos surgindo à direita ou esquerda do operador, em situação de subida ou descida, e foi observada a reação do mesmo ao estímulo. A amostra de 53 voluntários comprovou que para todos os grupos (níveis de experiência) o erro foi maior para o motocultivador. O trator apresentou $5,7 \%$ de erro enquanto que no motocultivador esse valor foi de $49,1 \%$. O resultado encontrado pelo modelo Usa Design concordou com os encontrados no teste e apontou graves deficiências em aspectos funcionais e de segurança no motocultivador.
\end{abstract}

Palavras-chave: Ergonomia. Operação. Erro.

Abstract: Santa Catarina showed a significant increase in its fleet of agricultural machinery in the past 40 years. For the historical origins, the state experienced a strong farm household that grows in small portions of land. This small size of farms boosted the purchase of farm machinery such as small power tillers. It is estimated that in Santa Catarina there are more than 20,000 machines like these. The initial design of this machine its use is intended for operations on foot position for possessing it commands designed for the walking posture. But a large proportion of power tillers is used to transport cargo and personnel, by adapting implement that allows driving in the sitting position. This modification is incomplete because it does not allow the installation of steering wheel. Thus the inadequacy of command increases the difficulty in driving the vehicle and may potentiate human error, leading to the accident. To compare the usability and rate of errors in triggering commands power tiller and tractors, the work used two methods: analysis uses the model Usa-Design (U-DC) and usability testing. A panel was positioned in front of the two agricultural machines simulated obstacles appearing on the right or left side of operator, in a position to rise or fall, and observed the reaction to the same stimulus. A sample of 53 volunteers showed that for all groups (experience levels) the error was greater for the power tiller. The tractor had $5.7 \%$ error while the power tiller this value was $49.1 \%$.

Revista Produção Online, Florianópolis, SC, v.15, n. 3, p.830-858, jul./set. 2015. 
The results found by U-DC model was similar with the found in the test and pointed out serious deficiencies in functional and safety aspects of power tiller.

Keywords: Ergonomics. Operation. Error.

\section{CONTEXTUALIZAÇÃO}

A mecanização da agricultura brasileira propiciou um incremento na produção e eficiência das operações no campo, mas também trouxe o aumento no número de acidentes. Dentre as máquinas agrícolas, os tratores são as que oferecem os maiores riscos. As causas de acidentes estão geralmente relacionadas à atitude dos operadores ou a problemas de interação deste com a máquina. Os projetos de máquinas agrícolas, especialmente tratores, têm evoluído muito em termos de ergonomia nos últimos anos. Porém máquinas como os motocultivadores não têm apresentado comparável evolução. Para mecanizar a produção agrícola buscou-se máquinas e equipamentos que reduzissem esforços físicos, reduzindo a mão-deobra e considerando o fator econômico. As máquinas que permitiram a manutenção da agricultura em pequenas parcelas, como na agricultura familiar, foram os microtratores e motocultivadores.

Estima-se que o Brasil possua mais de 820 mil tratores em operação (IBGE, 2007). A maior concentração está no Sul, onde Santa Catarina ocupa a quinta posição no país.

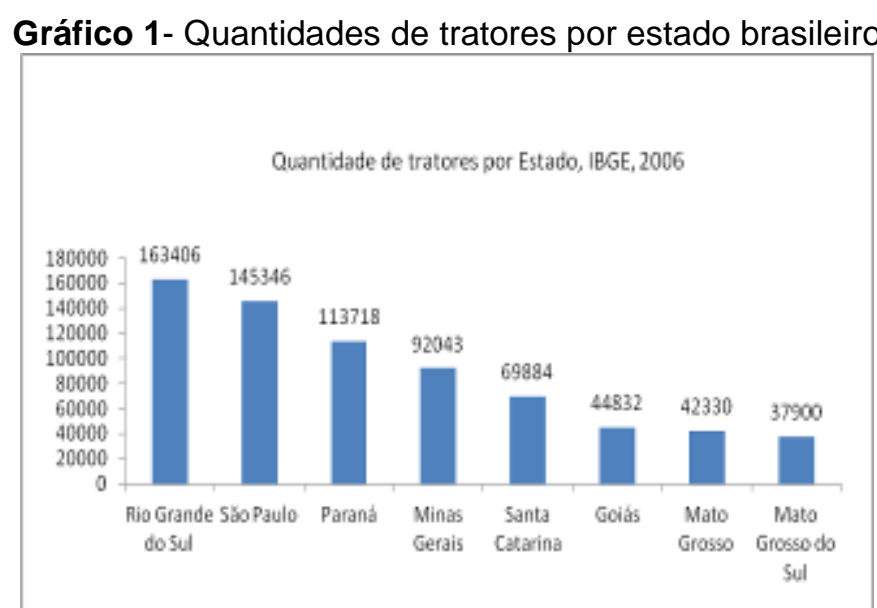

Fonte: Adaptado de IBGE (2007)

Segundo dados dos sensos agropecuários, IBGE (1996; 2007) o estado de Santa Catarina passou de pouco mais de 6 mil tratores em 1970 para quase 70 mil em 2006. Regiões com relevo e hidrografia desfavoráveis a grandes lavouras, a exemplo de Santa Catarina, tiveram que lançar mão de máquinas compatíveis com 
as operações agrícolas ali demandadas. Tratores de pequena potência e motocultivadores foram largamente adotados em propriedades de até 20 hectares. Nesse sentido este estado destacou-se por apresentar elevada porcentagem de tratores de potência inferior à $100 \mathrm{Cv}$.

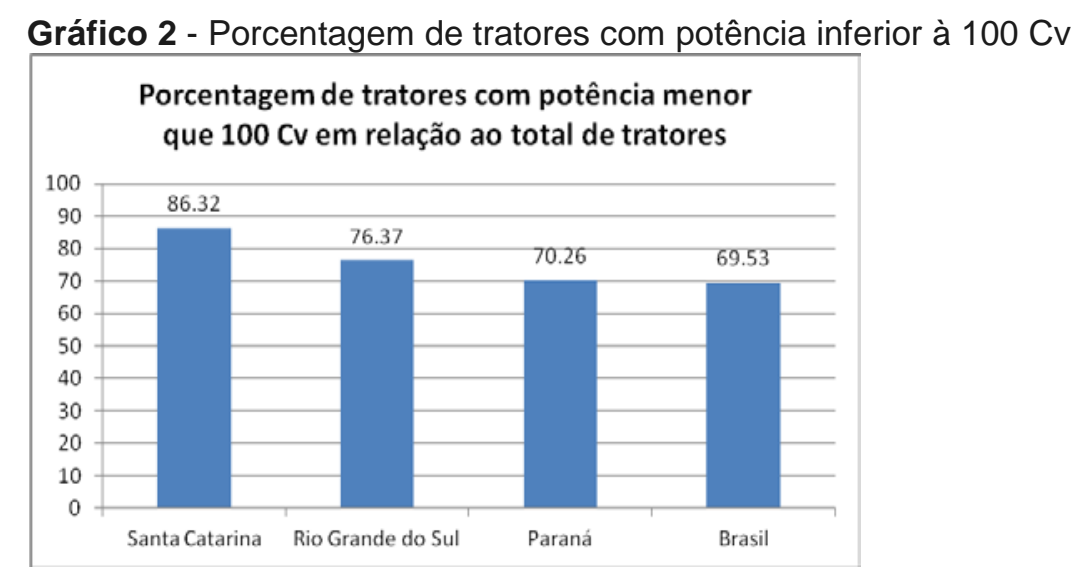

Fonte: Adaptado de IBGE (2007)

O Gráfico 2 mostra que Santa Catarina apresentava 86,32\% de sua frota de tratores com potência inferior à $100 \mathrm{Cv}$, valor bem superior à média do Brasil (69,53\%). Merece destaque a elevada porcentagem (41\%) de microtratores e motocultivadores, caracterizados pela potência inferior à 20 Cv (Gráfico 3).

Gráfico 3 - Classificação por potência de tratores

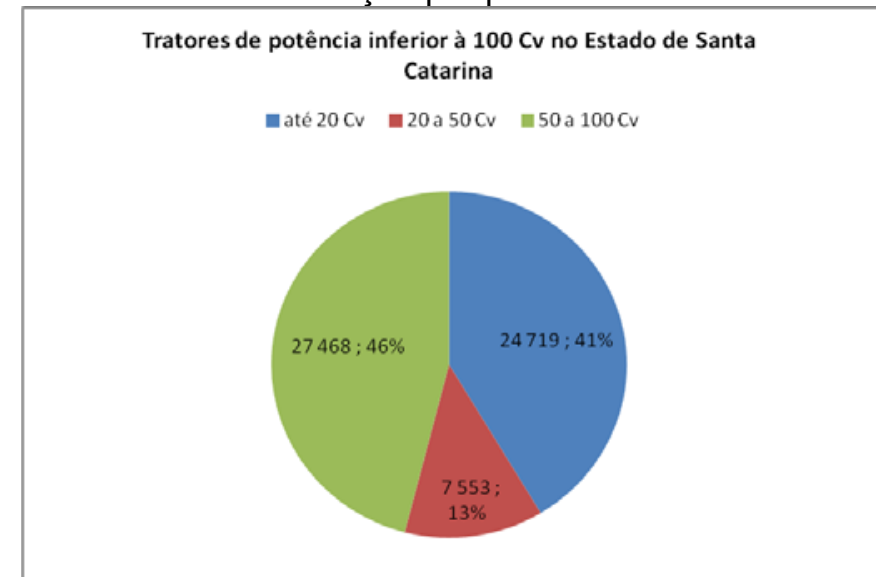

Fonte: Adaptado de IBGE (2007)

Considerando a faixa de potência até $20 \mathrm{Cv}$, estima-se que a maioria das mais de 24 mil máquinas são motocultivadores. Embora de pequena dimensão e peso, acidentes com esta máquina são frequentes e com elevado grau de lesões. Odorizzi et al., (2013) após investigarem 110 acidentes ocorridos com máquinas 
agrícolas em Santa Catarina, identificaram que $26 \%$ do total de acidentes ocorreram com motocultivadores.

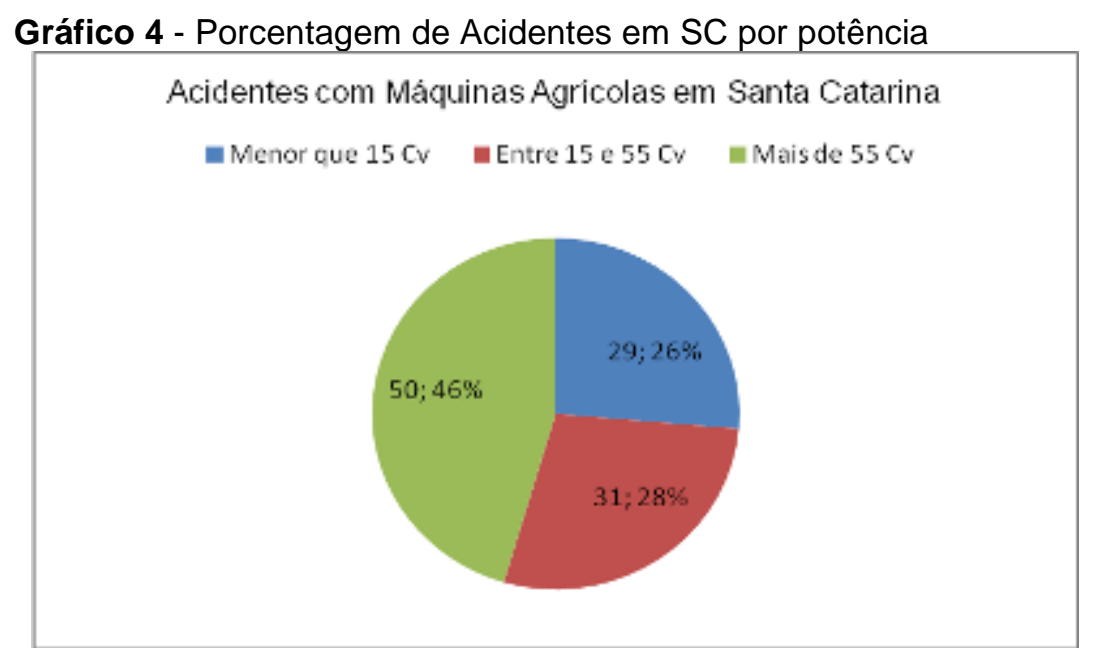

Fonte: Odorizzi et al. (2013)

\section{PROBLEMÁTICA}

Santa Catarina destaca-se no cenário nacional por possuir a maior frota de máquinas agrícolas com potência até $20 \mathrm{Cv}$, sendo que aproximadamente $41 \%$ das máquinas agrícolas com menos de 100 Cv são provavelmente de motocultivadores, o que representou mais de 24 mil unidades.

Pelo reduzido número de estudos no Brasil sobre acidentes e a escassez em instrumentos mais adequados à avaliação da situação de trabalho na agricultura (FERREIRA et al., 2014) esta proposta de emprego de ferramenta pode contribuir na mitigação de acidentes com máquinas agrícolas.

O relevo acidentado e a agricultura familiar fortemente desenvolvida em pequenos lotes de terras, aliado às diferenças construtivas da máquina em relação aos tratores, induz à investigação da usabilidade e índices de erros de operação com comandos de motocultivadores.

\section{OBJETIVO}

Comparar os sistemas de direção de tratores (por volante) com o sistema empregado nos motocultivadores (por manoplas) no que se refere à usabilidade e ao erro de acionamento. 


\section{PROCEDIMENTOS METODOLÓGICOS}

\subsection{Caracterização da Pesquisa}

A pesquisa foi dividida em dois momentos: avaliação da usabilidade do produto conforme os princípios de Jordan (1998) e ISO 9241-11 (1998) e teste de usabilidade, com a simulação de uso.

Seguindo a classificação proposta por Vieira (2008) e Gil (1991) a pesquisa enquadra-se como:

Quadro 1 - Classificação da pesquisa

\begin{tabular}{|l|l|}
\hline Classificação da pesquisa por Vieira (2008) \\
\hline Natureza & Pesquisa Aplicada \\
\hline Abordagem do problema & Pesquisa Quantitativa \\
\hline Classificação da pesquisa por Gil (1991) \\
\hline Objetivos & Pesquisa Explicativa \\
\hline Procedimentos técnicos & Bibliográfica, experimental e levantamento \\
\hline
\end{tabular}

\subsubsection{Avaliação da Usabilidade}

No processo de avaliação da usabilidade empregou-se o modelo Usa-Design (U-DC) (MERINO et al., 2012). O modelo baseia-se na ISO 9241-11 (1998) e nos princípios de Jordan (1998) utilizando a estrutura apresentada na figura a seguir. 
Figura 1 - Modelo Usa-Design

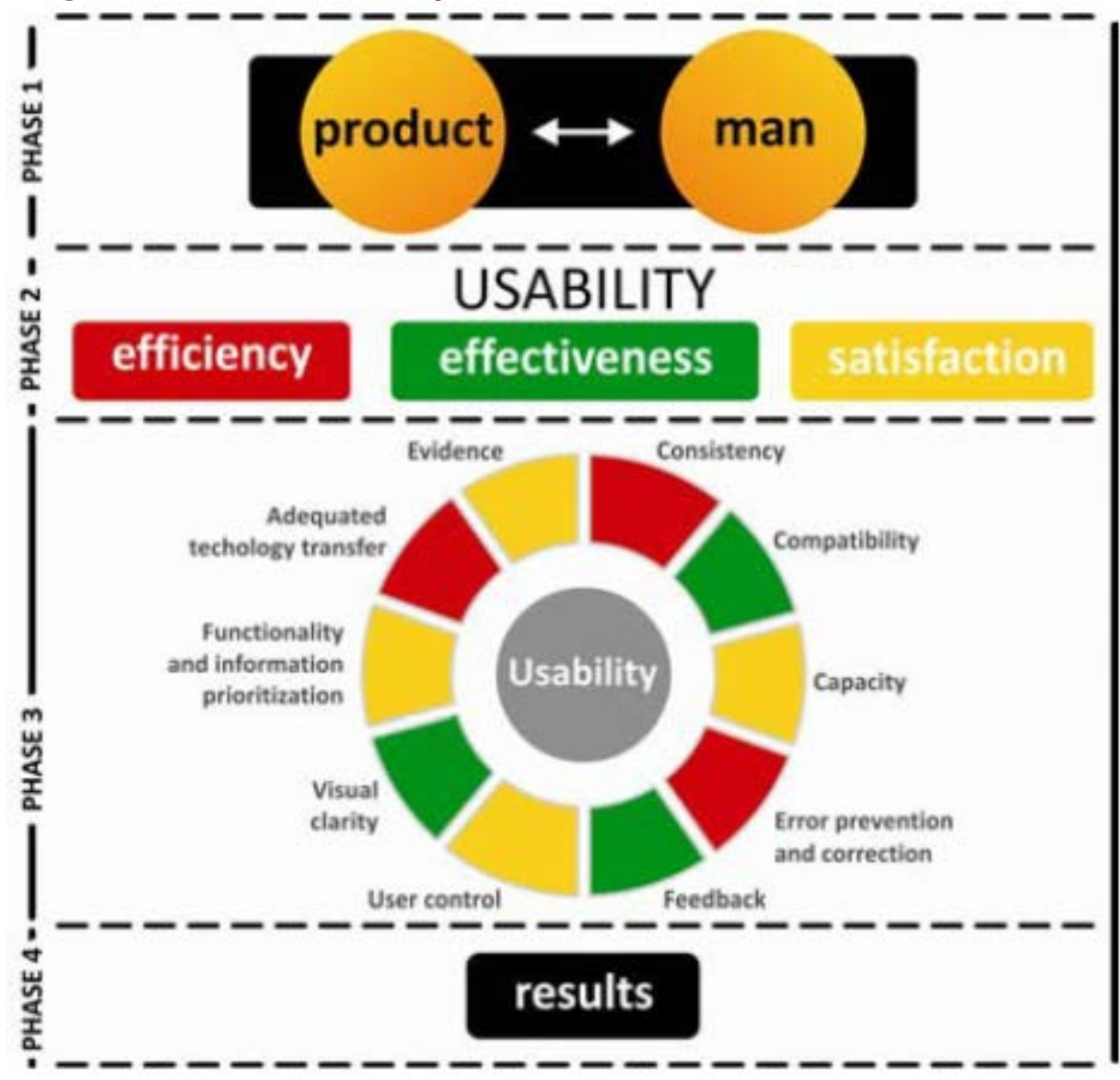

Fonte: Merino et al. (2012)

O método consiste na avaliação do produto com enfoque na usabilidade, onde na fase I é avaliado o contexto de uso do produto, podendo ser utilizadas técnicas como análise funcional, análise morfológica entre outros. Na fase II é avaliada a eficiência, eficácia e satisfação do usuário a respeito do produto. O resultado desta fase é representado por uma escala de cores, onde o vermelho representa "não atende", o amarelo "atende parcialmente" e o verde "atende". Uma escala numérica suporta a avaliação, conforme figura à seguir: 
Figura 2 - Fase II do Modelo Usa-Design

\begin{tabular}{|c|c|c|c|c|}
\hline & & $\begin{array}{l}\text { does not } \\
\text { attend }\end{array}$ & $\begin{array}{l}\text { partially } \\
\text { attends }\end{array}$ & $\begin{array}{l}\text { partially } \\
\text { attends }\end{array}$ \\
\hline \multirow{3}{*}{ 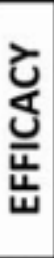 } & $\begin{array}{c}\text { Percentage of } \\
\text { targets achieved }\end{array}$ & $0-59 \%$ & $60-89 \%$ & $90-100 \%$ \\
\hline & $\begin{array}{c}\text { Percentage of } \\
\text { users completing } \\
\text { the task with sucess }\end{array}$ & $0-59 \%$ & $60-89 \%$ & $90-100 \%$ \\
\hline & $\begin{array}{l}\text { Average accuracy } \\
\text { of completed tasks }\end{array}$ & $0-59 \%$ & $60-89 \%$ & $90-100 \%$ \\
\hline \multirow{3}{*}{ 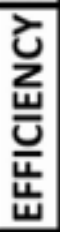 } & $\begin{array}{c}\text { Time to } \\
\text { complete a task }\end{array}$ & $0-59 \%$ & $60-89 \%$ & $90-100 \%$ \\
\hline & $\begin{array}{l}\text { Tasks completed } \\
\text { per unit of time }\end{array}$ & - & - & - \\
\hline & $\begin{array}{c}\text { Financial cost to } \\
\text { accomplish the task }\end{array}$ & $0-59 \%$ & $60-89 \%$ & $90-100 \%$ \\
\hline \multirow{3}{*}{ 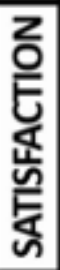 } & Satisfaction scale & $0-59 \%$ & $60-89 \%$ & $90-100 \%$ \\
\hline & Use frequency & $0-59 \%$ & $60-89 \%$ & $90-100 \%$ \\
\hline & $\begin{array}{l}\text { Complaints } \\
\text { frequency }\end{array}$ & $100-70 \%$ & $69-11 \%$ & $10-0 \%$ \\
\hline
\end{tabular}

Fonte: Merino et al. (2012)

$\mathrm{Na}$ fase III a estrutura de medição se utiliza de uma escala cromática (qualitativa) e também numérica (quantitativa) baseada nos dez princípios da usabilidade de Jordan (1998), conforme figura a seguir:

Figura 3 - Estrutura de medição da fase III

\begin{tabular}{|c|c|c|c|}
\cline { 2 - 4 } \multicolumn{1}{c|}{} & \multicolumn{3}{c|}{ MEASUREMENT } \\
\hline QUANTITATIVE & 1 & 2 & 3 \\
\hline QUALITATIVE & & & \\
\hline READING & $\begin{array}{c}\text { does not } \\
\text { attend }\end{array}$ & $\begin{array}{c}\text { partially } \\
\text { attends }\end{array}$ & $\begin{array}{c}\text { completely } \\
\text { attends }\end{array}$ \\
\hline
\end{tabular}

Fonte: Merino et al. (2012)

Os resultados da avaliação global são apresentados de forma descritiva na fase IV deste modelo.

\subsubsection{Teste de Usabilidade}

O teste foi conduzido em uma instituição de ensino técnico agrícola e contou com uma amostra de 53 estudantes, sendo 13 do sexo feminino e 40 do masculino, com faixa etária entre 15 e 20 anos. Destes, 33 pertenciam à agricultura familiar. 
O teste avaliou a usabilidade de duas máquinas agrícolas de distintas concepções: um trator modelo Valmet modelo 785 , ano de fabricação 1994, com potência de 75 cv e um motocultivador modelo Kubota Tobatta, ano 1995, de $16 \mathrm{cv}$ de potência. Em frente a cada máquina agrícola, em momentos alternados, foi suspenso por guindaste um painel com lâmpadas coloridas. Composto de uma prancha de $2 \mathrm{~m} \times$ 0,3 $\mathrm{m}$ com 4 lâmpadas, sendo uma em cada extremidade e duas no centro (uma sobre a outra). As fotos 1 e 2 , a seguir, ilustram a composição para o teste.

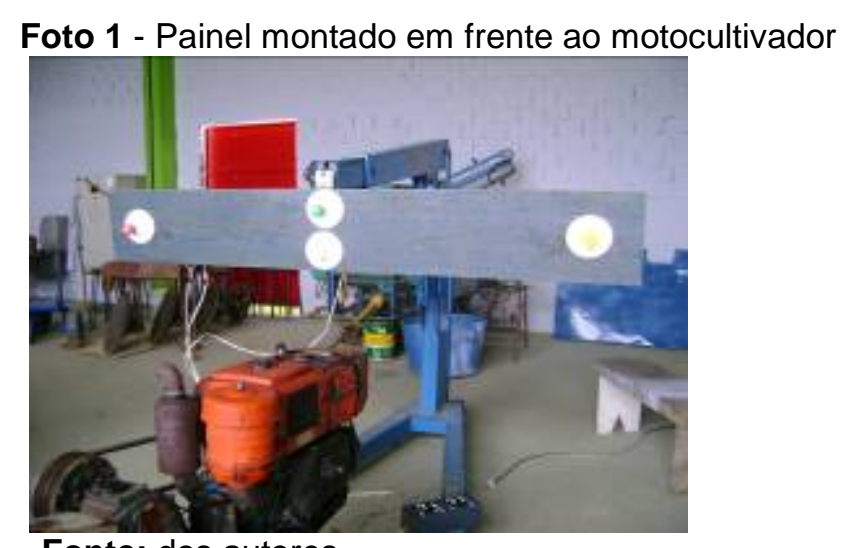

Fonte: dos autores

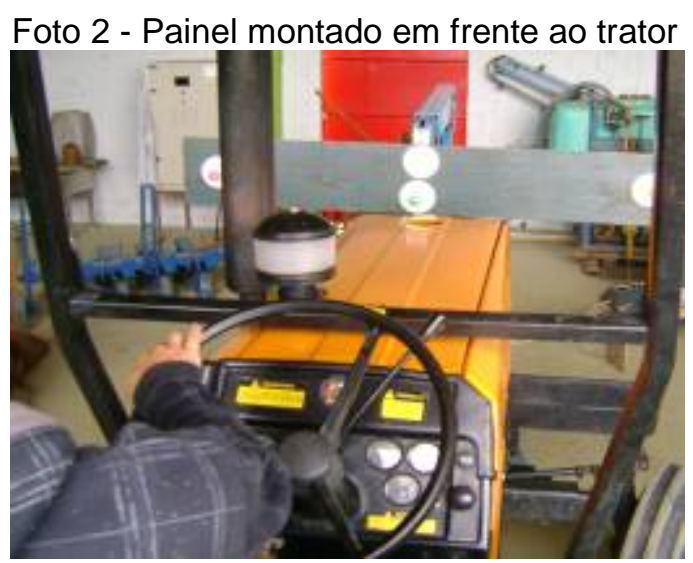

Fonte: dos autores

Coletivamente os usuários foram orientados quanto ao funcionamento do sistema de direção do trator e do motocultivador. Receberam instrução quanto ao funcionamento do teste bem como a simbologia das lâmpadas no painel, como segue: 
Quadro 2 - Quadro explicativo do painel

\begin{tabular}{|c|c|c|}
\hline Cor & Posição & Significado \\
\hline Vermelha & $\begin{array}{c}\text { Extremidade Direita e Extremidade } \\
\text { Esquerda }\end{array}$ & $\begin{array}{c}\text { Indica obstáculo a desviar, podendo estar à } \\
\text { direita ou à esquerda da máquina }\end{array}$ \\
\hline Verde & Central Superior e Central Inferior & $\begin{array}{c}\text { Lâmpada superior indica máquina operando em } \\
\text { aclive e luz inferior indica máquina operando em } \\
\text { declive }\end{array}$ \\
\hline
\end{tabular}

Foram também orientados a reagir imediatamente ao acionamento das lâmpadas, simulando o aparecimento de um obstáculo. Cada indivíduo foi convidado a posicionar-se sentado em cada uma das máquinas agrícolas, que apresentavamse ligadas e em rotação de trabalho. Estando o usuário com as duas mãos sobre os comandos de direcionamento (volante para $o$ trator e manoplas para 0 motocultivador) o auxiliar ligava duas lâmpadas simultaneamente, uma central e uma lateral. A resposta do indivíduo ao sinal era avaliada por outra pessoa posicionada em frente ao usuário. As reações eram apontadas como certo se o usuário reagiu evitando o choque com o obstáculo e errado se não esboçou reação ou se reagiu direcionando a máquina sobre o obstáculo representado pela luz. O teste foi aplicado para cada uma das máquinas agrícolas. Cada indivíduo, após o teste em cada máquina, respondeu o seguinte questionário:

Quadro 3 - Questionário aplicado ao usuário
\begin{tabular}{|c|c|c|}
\hline Ordem & Questão & \multicolumn{1}{c|}{ Alternativas } \\
\hline 1 & Idade? & \multicolumn{1}{|c|}{} \\
\hline 2 & Já sofreu acidente com a máquina? & $\begin{array}{l}\text { ( ) sim } \\
\text { ( ) não }\end{array}$ \\
\hline 3 & $\begin{array}{c}\text { Em comparação com o trator, o } \\
\text { motocultivador é: }\end{array}$ & $\begin{array}{l}\text { ( ) mais seguro } \\
\text { ( ) menos seguro } \\
\text { ( ) indiferente }\end{array}$ \\
\hline 4 & Possui motocultivador na família? & $\begin{array}{l}\text { ( ) sim } \\
\text { ( ) não }\end{array}$ \\
\hline 5 & Quantos anos de experiência com a \\
máquina? & $\begin{array}{l}\text { ( ) nenhuma } \\
\text { ( ) menos de 1 ano } \\
\text { ( ) mais de 1 ano }\end{array}$ \\
\hline
\end{tabular}

\section{Desenvolvimento}

\subsection{Tratores}

Segundo a norma para ensaio de máquinas agrícolas OECD (2012), define-se trator como um veículo automotor com pelo menos dois eixos, ou esteiras, destinadas a realizar as seguintes operações para fins agrícolas e florestais: puxar 
reboques; transportar, puxar ou empurrar implementos ou máquinas agrícolas e florestais e, quando necessário, fornecer potência para operá-los com o trator em marcha ou parado. Um trator também pode ser definido como sendo uma unidade móvel de potência, em que se acoplam implementos e máquinas com diversas funções, tendo suas características voltadas para o uso nas operações agrícolas (SCHLOSSER, 2002). São caracterizados por possuírem 4 rodas, normalmente com eixo de tração traseiro, com ou sem tração dianteira auxiliar, cujo sistema de direcionamento é por esterçamento das rodas dianteiras comandadas por volante. $\mathrm{O}$ sistema de embreagem e freio assemelha-se aos encontrados em automóveis.

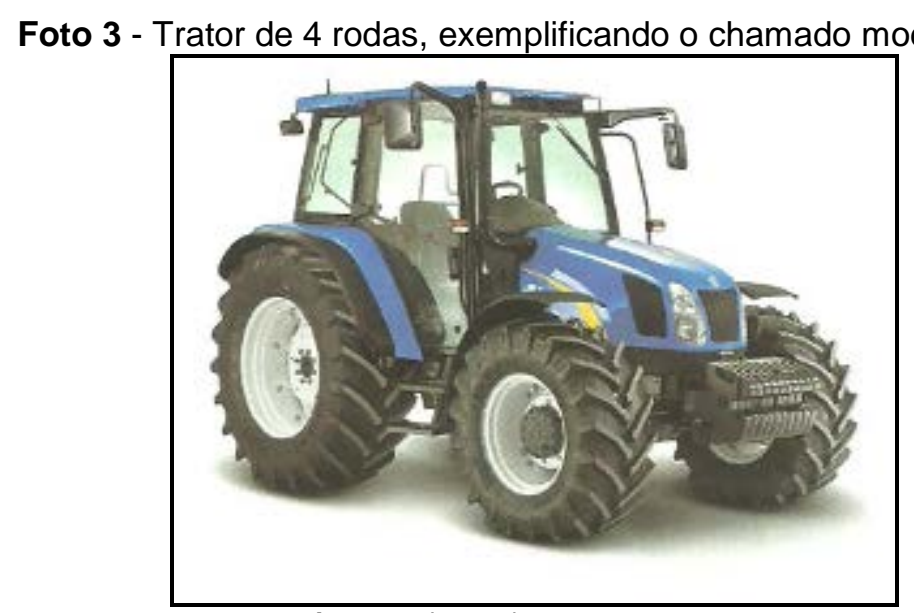

Fonte: Márquez (2011)

Segundo Menegas et al., (2006), com o passar do tempo o trator foi sendo aperfeiçoado para exercer outras tarefas além de tracionar máquinas de preparo do solo. Esse desenvolvimento visou a sua melhor adaptação ao trabalho, isto é, enfocando a relação trabalho-máquina deixando de fora uma parte de igual importância: o homem. Somente com o surgimento da ergonomia após a II Guerra Mundial é que se relacionou o homem ao trator e os projetos passaram a contar com dois fatores de preocupação para os projetistas: segurança e bem-estar do operador. A partir dessa nova relação homem-máquina muitos trabalhos antropométricos foram realizados com o intuito de se determinar medidas padrões do homem e, de posse desses dados, os tratores passaram a ser projetados de forma a se adaptarem ao homem e não ao contrário como vinha acontecendo.

Mais recentemente, estudos a respeito da ergonomia cognitiva foram realizados a fim de aprimorar a relação homem-máquina e, consequentemente, melhorar o posto de trabalho e a produtividade. 


\subsection{Motocultivadores}

A maioria dos motocultivadores utilizam motores monocilíndricos refrigerados a ar. Normalmente são empregados motores à diesel de quatro tempos com potência entre 10 e 20 cv. A cilindrada varia entre 250 e 500 centímetros cúbicos com um regime de funcionamento máximo de 3800 rotações por minuto (MÁRQUEZ, 2011).

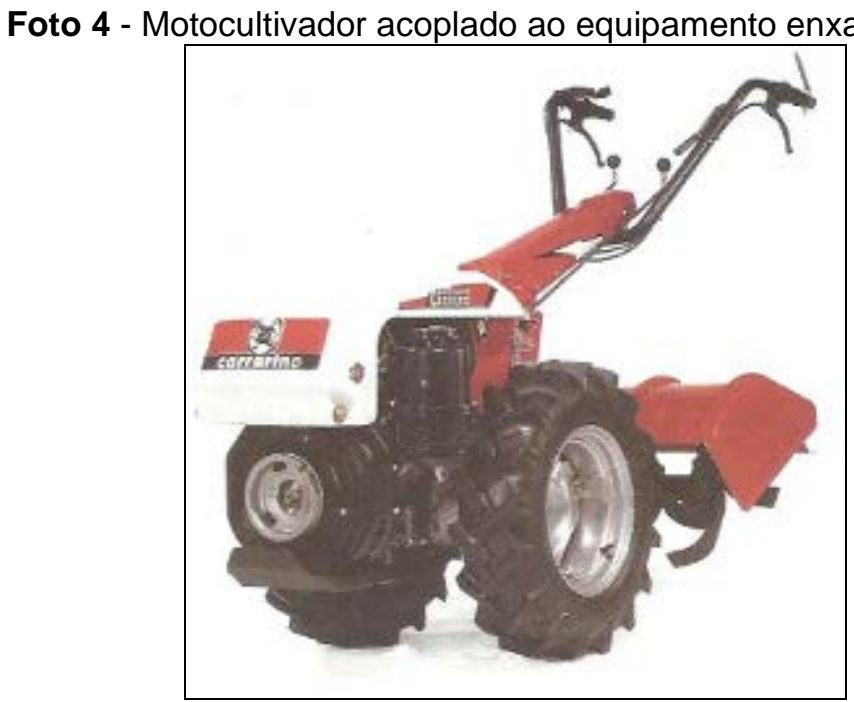

Fonte: Márquez (2011)

Por possuírem apenas um eixo e duas rodas, não se classificam como tratores, tampouco como microtratores, como popularmente são chamados. Segundo Veiga et al. (2014), pelas dimensões reduzidas, o motocultivador teve sua utilização ampliada em regiões de relevo acidentado e em propriedades de até 20 hectares. A condição de trabalho do operador inclui todos os fatores do ambiente, que têm um efeito sobre o sistema homem-máquina. Entre esses fatores, a vibração mecânica e o ruído são os mais importantes, pois aceleram a fadiga e afetam a sensibilidade de reação do operador. A Foto 5 apresenta a configuração do motocultivador com adaptação da carreta, usada para o transporte de carga e pessoas. 
Foto 5 - Motocultivador com adaptação para a posição sentada

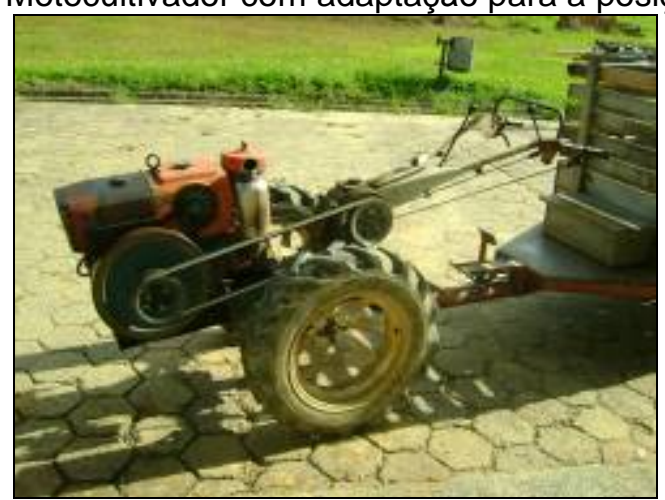

Fonte: Dos autores

Tanto na configuração para operação em pé como sentado, o sistema de direcionamento é por embreagem em cada roda de tração, ou seja, aciona-se a embreagem de uma roda e a outra traciona direcionando a máquina. O resultado do acionamento (a direção que o motocultivador irá tomar) depende do relevo, se em aclive ou declive.

\subsection{Usabilidade}

Um dos aspectos mais relevantes na escolha de um produto pelo cliente é a capacidade de se adaptar ao uso deste e o quanto o produto atende à sua demanda técnica, ou seja, se realiza o que o usuário imagina que pode alcançar com esse objeto ou serviço.

Conforme a ISO 9241-11 (1998), a usabilidade é definida como a capacidade de um produto ser usado por usuários específicos para atingir objetivos específicos com eficácia, eficiência e satisfação em um contexto específico de uso. Jordan (1998) definiu esses três parâmetros da seguinte forma: Eficácia: refere-se à extensão na qual uma meta é alcançada ou uma tarefa é realizada; Eficiência: refere-se à quantidade de esforço necessário para se atingir a meta. Quanto menor for o esforço, maior será a eficiência; Satisfação: refere-se ao nível de conforto que os usuários percebem quando utilizam o produto. Sua aceitação pelos usuários para atingir as suas metas.

Também a ISO 9241-11 (1998) define a usabilidade não somente como propriedade intrínseca do produto isoladamente, mas dependente do contexto específico de uso, ou seja, quem está utilizando o produto, para qual finalidade e o tipo específico de ambiente.

Revista Produção Online, Florianópolis, SC, v.15, n. 3, p.830-858, jul./set. 2015. 
Pelas definições de bibliografia qualificada pode-se concluir que a usabilidade é, portanto, uma propriedade da interação entre produto, usuário e a tarefa que este usuário está realizando.

Os princípios para o design com usabilidade proposto por Jordan (1998) são explicados a seguir, com exemplos ligados a máquinas agrícolas, de como cada um afeta a usabilidade do produto.

\section{Coerência}

Projetar com coerência significa que características similares devem ser realizadas da mesma maneira. Como um usuário ganha experiência com o produto, ele pode aplicar esse conhecimento para ajudar a alcançar os objetivos de outra. Incoerências podem levar a erros. Um exemplo em máquinas agrícolas é o freio de estacionamento (freio de mão). O emprego da mesma concepção de sistemas utilizados em automóveis torna mais familiar a utilização do freio em um trator.

\section{Compatibilidade}

A compatibilidade deve assegurar que a maneira que um produto funciona atende às expectativas do usuário, baseada no conhecimento que ele tem do mundo ao seu redor. A compatibilidade se difere da coerência, uma vez que a coerência se refere a regularidades no design dentro de produtos similares. Já a compatibilidade se refere às regularidades do design entre um produto e as fontes externas. O pedal do acelerador do trator segue a expectativa do usuário de que pisando no pedal (para baixo) aumenta-se a velocidade da máquina

\section{Capacidade}

Ao interagir com um produto um usuário pode usar uma variedade de suas habilidades ou "canais". É importante que quando se usa um produto, nenhuma das habilidades do usuário seja sobrecarregada, porque se isso ocorrer tem-se um problema de usabilidade. O emprego da direção hidráulica em tratores evita a sobrecarga física pela excessiva necessidade de manobras em operações no campo.

\section{Retroalimentação}

É importante que o produto, por suas interfaces, ofereçam reações claras sobre as ações realizadas pelo usuário. A falta de uma indicação significativa sobre os resultados dessas ações pode fazer com que o usuário repita a operação ou se sinta perdido. Um exemplo disso é o emprego do conta-giros que permite visualizar a rotação aplicada pelo operador.

Revista Produção Online, Florianópolis, SC, v.15, n. 3, p.830-858, jul./set. 2015. 


\section{Prevenção de erro e recuperação}

Parece inevitável que usuários cometam erros de tempo em tempo quando usam um produto. No entanto, os produtos podem ser projetados com a possibilidade de minimizar a ocorrência de erros e o usuário recuperar, de forma rápida erro que tenha cometido. É comum em tratores de grande porte a utilização de sensor que impede que o operador dê a partida na máquina quando uma marcha estiver engatada. Faz-se necessário deixar em ponto morto ou acionar a embreagem antes da ignição.

\section{Controle do usuário}

Os produtos devem ser projetados de forma a oferecer o máximo de controle aos usuários sobre as interações, ou seja, sobre as ações tomadas no produto. Uma vez engatada uma determinada marcha do trator esta não pode desengatar sozinha pois poderia pôr em risco o operador, que ficaria momentaneamente sem controle sobre a máquina.

\section{Clareza visual}

É importante que a informação seja apresentada de forma que ela possa ser lida rápida e facilmente sem causar qualquer confusão. As informações de feedback incluem-se nesse princípio. O painel de uma máquina agrícola deve expressar com clareza uma condição de perigo para a máquina ou para o operador, a exemplo da pressão do óleo do motor ou falta de fluido de arrefecimento no radiador.

\section{Priorização da funcionalidade}

Projetar um produto de maneira que a funcionalidade e a informação mais importantes sejam facilmente acessadas pelo usuário. A velocidade do trator e a rotação do motor são informações prioritárias e devem destacar-se perante as demais nos painéis dessa máquina.

\section{Transferência adequada de tecnologia}

Tecnologias que foram desenvolvidas para um propósito sendo aplicadas para outra área podem trazer grandes benefícios para os usuários. No entanto, se feitas sem cuidado suficiente podem também trazer problemas. O emprego do Sistema de Posicionamento Global (GPS), que nasceu na indústria aero-espacial, permite à agricultura moderna maximizar resultados e diminuir erros humanos.

\section{Evidência}

Produtos devem ser projetados de forma que seja claro a forma como operálos. Projetar um produto de maneira que sejam dados indícios de como ele funciona Revista Produção Online, Florianópolis, SC, v.15, n. 3, p.830-858, jul./set. 2015. 
e o método para operá-lo. Ao sentar-se no posto de trabalho de uma máquina agrícola o operador deve, com facilidade, compreender as funções dos comandos principais que, a priori, deveriam estar próximos e bem destacados.

No projeto de máquinas e equipamentos agrícolas motorizados os princípios da coerência, compatibilidade, feedback e prevenção de erros merecem especial atenção. Por se tratar de posto de trabalho móvel e envolver uma diversidade de comandos, às vezes superior ao encontrado nos veículos de passeio ou carga, torna a máquina agrícola em especial o trator exigente em uma carga mental elevada e maior velocidade nas reações e correções de curso.

Veiga et al., (2013) em pesquisa realizada com comandos de tratores de marcas distintas apontaram que os erros de acionamento foram influenciados pela sua concepção. O estereótipo com maior compatibilidade apresentou menor índice de erro (19\%). Já o comando com menor concordância com o estereótipo apresentou erro maior (33\%).

\subsection{Acidente e erro humano}

Segundo Debiasi et al., (2004) a maior parte dos acidentes com conjuntos tratorizados é causada por atitudes inseguras, as quais poderiam ser evitadas através de medidas de segurança que atuassem nas causas específicas, como a perda de controle em aclive ou declive e operação do trator em condições extremas.

Junior e Sell (2004) apontam que as teorias de acidentes de trabalho evoluíram de uma visão em que o trabalhador era sempre o culpado pelo acidente, até uma que admite a coexistência de diversas causas para os acidentes, aliviando a carga psíquica de trabalhadores enquanto operadores de máquinas diversas.

Pelos modelos sequenciais de acidentes, as falhas humanas estão entre os eventos encadeadores de maior relevância.

Dougherty (1997) afirmou que o erro humano irá ocorrer e distribuir-se de acordo com a situação, pois esta pode sugerir ou induzir a inclusão de atitudes erradas pelo indivíduo ou ainda interferindo no tempo de resposta, comprometendo o desempenho humano.

Para lida (2005) o erro recai normalmente no domínio da percepção, processamento humano das informações ou interações inadequadas com o sistema. 


\section{ANÁLISE E DISCUSSÃO}

\subsection{Resultados da avaliação de usabilidade}

$\mathrm{Na}$ fase I do modelo U-D@ a análise global de funcionalidade demonstrou que as duas máquinas apresentaram funções básicas similares, que são: acelerador, embreagem, freio e troca de velocidades (câmbio). O maior diferencial entre as duas estava no sistema de direção: uma apresentava volante (trator) e outra rabiças (motocultivador).

A seguir são apresentados em quadros os resultados das fases II e III do modelo U-D@ para cada uma das cinco funções de cada máquina.

\subsubsection{Consistência}

Quadro 4 - Análise do Princípio da Consistência para Trator e Motocultivador

\begin{tabular}{|c|c|c|}
\hline Função & Trator & Motocultivador \\
\hline Acelerador & $\begin{array}{l}\text { Apresenta dois aceleradores, de mão e } \\
\text { de pé. O primeiro do tipo rotação e } \\
\text { segundo por pedal. }\end{array}$ & $\begin{array}{l}\text { Apresenta apenas acelerador de mão, } \\
\text { do tipo alavanca de torção. }\end{array}$ \\
\hline Embreagem & $\begin{array}{l}\text { As duas embreagens são de concepções } \\
\text { distintas, sendo a do motor-caixa do tipo } \\
\text { pedal e da Tomada de Potência do tipo } \\
\text { alavanca. }\end{array}$ & $\begin{array}{l}\text { As duas embreagens são de diferentes } \\
\text { concepções, sendo as individuais (para } \\
\text { cada roda) do tipo manete e a } \\
\text { embreagem geral (motor } \\
\text { implementos) do tipo alavanca. }\end{array}$ \\
\hline Freio & $\begin{array}{l}\text { São dois sistemas: freio de manobra e } \\
\text { freio de estacionamento. O primeiro é } \\
\text { dividido em dois pedais (um por roda) e o } \\
\text { segundo é acionado por alavanca. }\end{array}$ & $\begin{array}{l}\text { Os sistemas de freio são dois: uma } \\
\text { alavanca para freio no eixo do } \\
\text { motocultivador e outro na carreta, que } \\
\text { freia o eixo traseiro. }\end{array}$ \\
\hline $\begin{array}{l}\text { Troca de } \\
\text { Velocidade }\end{array}$ & $\begin{array}{l}\text { A caixa de câmbio de quatro marchas é } \\
\text { acionada por alavanca, assim como a } \\
\text { segunda caixa de redução com duas } \\
\text { relações. }\end{array}$ & $\begin{array}{l}\text { A caixa de quatro marchas é acionada } \\
\text { por alavanca, já a redução é realizada } \\
\text { pela troca de posição de polias. }\end{array}$ \\
\hline Direção & $\begin{array}{l}\text { O volante de rotação utilizado é idêntico } \\
\text { ao modelo emprego em automóveis. }\end{array}$ & $\begin{array}{l}\text { A rabiça do motocultivador é } \\
\text { semelhante ao guidão das } \\
\text { motocicletas, porém fica afastada do } \\
\text { ponto de rotação do eixo. }\end{array}$ \\
\hline Avaliação & Atende & Atende Parcialmente \\
\hline
\end{tabular}




\subsubsection{Compatibilidade}

Quadro 5 - Análise do Princípio da Compatibilidade para Trator e Motocultivador

\begin{tabular}{|c|c|c|}
\hline Função & Trator & Motocultivador \\
\hline Acelerador & $\begin{array}{l}\text { Tanto o acelerador manual como o de pé } \\
\text { apresentam compatibilidade com o } \\
\text { estereótipo popular. }\end{array}$ & $\begin{array}{l}\text { O acelerador de mão apresenta } \\
\text { compatibilidade pois aumenta a rotação } \\
\text { no sentido horário. }\end{array}$ \\
\hline Embreagem & $\begin{array}{l}\text { As duas embreagens são de concepções } \\
\text { distintas, sendo a do motor-caixa do tipo } \\
\text { pedal e da Tomada de Potência do tipo } \\
\text { alavanca. }\end{array}$ & $\begin{array}{l}\text { A embreagem individual (por roda) é do } \\
\text { tipo manete e contraria o estereótipo } \\
\text { básico pois o lado de acionamento } \\
\text { depende da declividade, na subida } \\
\text { deve-se acionar um lado, já na descida } \\
\text { o outro. } \\
\text { A embreagem geral do tipo alavanca } \\
\text { fica entre a posição "engatado" e } \\
\text { "frenado", sendo também de difícil } \\
\text { compreensão. }\end{array}$ \\
\hline Freio & $\begin{array}{l}\text { Os dois sistemas são compatíveis, tanto a } \\
\text { alavanca como o pedal. }\end{array}$ & $\begin{array}{l}\text { Tanto a alavanca para freio no eixo do } \\
\text { motocultivador como o da carreta são } \\
\text { compatíveis. }\end{array}$ \\
\hline $\begin{array}{l}\text { Troca de } \\
\text { Velocidade }\end{array}$ & $\begin{array}{l}\text { Tanto a caixa de câmbio como a caixa de } \\
\text { redução apresentam-se compatíveis com } \\
\text { os estereótipos. }\end{array}$ & $\begin{array}{l}\text { A caixa de quatro marchas é acionada } \\
\text { por alavanca e apresenta } \\
\text { compatibilidade. Já a redução realizada } \\
\text { pela troca de polias é complexa e de } \\
\text { difícil compreensão. }\end{array}$ \\
\hline Direção & $\begin{array}{l}\text { O volante obedece ao estereótipo popular } \\
\text { que diz que a rotação no sentido horário } \\
\text { conduz o veículo para a direita e anti- } \\
\text { horária para a esquerda. }\end{array}$ & $\begin{array}{l}\text { A rabiça segue o estereótipo do guidão, } \\
\text { porém é necessário também o } \\
\text { acionamento da embreagem para } \\
\text { possibilitar o giro. Assim, para dobrar à } \\
\text { direita em um aclive é necessário } \\
\text { debrear a roda direira. Em declive é } \\
\text { necessário debrear a roda esquerda. }\end{array}$ \\
\hline Avaliação & Atende & Não Atende \\
\hline
\end{tabular}

\subsubsection{Capacidade}

Quadro 6 - Análise do Princípio da Capacidade para Trator e Motocultivador

\begin{tabular}{|c|c|c|}
\hline Função & Trator & Motocultivador \\
\hline Acelerador & $\begin{array}{l}\text { Tanto o acelerador manual como o de pé } \\
\text { apresentam-se leves e intuitivos. }\end{array}$ & $\begin{array}{l}\text { O acelerador de mão apresenta-se } \\
\text { impreciso e não mantém a rotação } \\
\text { devido à forte vibração no manete. }\end{array}$ \\
\hline Embreagem & $\begin{array}{l}\text { A embreagem de pedal apresenta baixo } \\
\text { peso e boa posição em relação ao } \\
\text { acento. Já a alavanca da embreagem } \\
\text { manual é pesada e imprecisa, além de } \\
\text { estar posicionada à esquerda do } \\
\text { operador. }\end{array}$ & $\begin{array}{l}\text { A embreagem individual (para cada } \\
\text { roda) exige pega em pinça desvio } \\
\text { ulnar acentuado. Já a embreagem } \\
\text { geral exige que o operador se afaste } \\
\text { do encosto do posto de trabalho. }\end{array}$ \\
\hline Freio & $\begin{array}{l}\text { Os dois sistemas são leves e permitem } \\
\text { acionamento com operador sentado. }\end{array}$ & $\begin{array}{l}\text { O freio por alavanca exige que o } \\
\text { operador levante-se do acento ou } \\
\text { fique sem encosto lombar (depende } \\
\text { da estatura do operador). Já o freio } \\
\text { da carreta pode ser acionado da } \\
\text { posição sentado e sem grande } \\
\text { esforço físico. }\end{array}$ \\
\hline
\end{tabular}


Quadro 6 - Análise do Princípio da Capacidade para Trator e Motocultivador

(conclusão)

\begin{tabular}{|c|l|l|}
\hline Função & \multicolumn{1}{|c|}{ Trator } & \multicolumn{1}{|c|}{ Motocultivador } \\
\hline $\begin{array}{c}\text { Troca de } \\
\text { Velocidade }\end{array}$ & $\begin{array}{l}\text { Ambas as caixas de câmbio } \\
\text { posicionam-se entre as pernas do } \\
\text { operador e exigem flexão do tronco e } \\
\text { perda do apoio lombar. }\end{array}$ & $\begin{array}{l}\text { A caixa de marchas exige a flexão do } \\
\text { tronco e perda do apoio lombar. Já a } \\
\text { redução realizada pela troca de polias é } \\
\text { complexa e exige grande esforço físico. }\end{array}$ \\
\hline Direção & $\begin{array}{l}\text { A assistência hidráulica permite o giro } \\
\text { do volante com emprego de pouco } \\
\text { mais de 1 Kgf. }\end{array}$ & $\begin{array}{l}\text { A força necessária para fazer uma } \\
\text { conversão, parado, foi } \\
\text { aproximadamente 15 Kgf. }\end{array}$ \\
\hline Avaliação & \multicolumn{1}{|c|}{ Atende } & \multicolumn{1}{c|}{ Não atende } \\
\hline
\end{tabular}

\subsubsection{Retroalimentação (feedback)}

Quadro 7 - Análise do Princípio da Retroalimentação para Trator e Motocultivador

\begin{tabular}{|c|l|l|}
\hline Função & \multicolumn{1}{|c|}{ Trator } & \multicolumn{1}{|c|}{ Motocultivador } \\
\hline Acelerador & $\begin{array}{l}\text { Tanto para o acelerador manual como } \\
\text { o de pé a rotação e velocidade são } \\
\text { expressas em mostradores no painel } \\
\text { da máquina. }\end{array}$ & $\begin{array}{l}\text { O } \\
\text { qualquelerador feedback ao operador, não há } \\
\text { painel de mostradores e sequer marcações } \\
\text { indicativas na alavanca. }\end{array}$ \\
\hline Embreagem & $\begin{array}{l}\text { Não há retroalimentação senão a } \\
\text { reação da máquina ao comando e a } \\
\text { posição final dos elementos (alavanca } \\
\text { e pedal). }\end{array}$ & $\begin{array}{l}\text { Não há retroalimentação senão a reação } \\
\text { da máquina ao comando e a posição final } \\
\text { dos elementos (alavanca e manetes). }\end{array}$ \\
\hline Freio & $\begin{array}{l}\text { Não há retroalimentação senão a } \\
\text { reação da máquina ao comando e a } \\
\text { posição final dos elementos (alavanca } \\
\text { e pedal). }\end{array}$ & $\begin{array}{l}\text { Não há retroalimentação senão a reação } \\
\text { da máquina ao comando e a posição final } \\
\text { dos elementos (alavanca e pedal). }\end{array}$ \\
\hline Troca de & $\begin{array}{l}\text { Não há retroalimentação senão a } \\
\text { reação da máquina ao comando e a } \\
\text { posição final dos elementos } \\
\text { (alavancas). }\end{array}$ & $\begin{array}{l}\text { Não há retroalimentação senão a reação } \\
\text { da máquina ao comando e a posição final } \\
\text { dos elementos (alavanca e correia). }\end{array}$ \\
\hline Delocidade & $\begin{array}{l}\text { Não há retroalimentação senão a } \\
\text { reação da máquina ao comando e a } \\
\text { posição final do volante. }\end{array}$ & $\begin{array}{l}\text { Não há retroalimentação senão a reação } \\
\text { da máquina ao comando e a posição final } \\
\text { da rabiça. }\end{array}$ \\
\hline Avaliação & Atende & Não Atende \\
\hline
\end{tabular}

\subsubsection{Prevenção de erros}

Quadro 8 - Análise do Princípio da Prevenção de Erros para Trator e Motocultivador

\begin{tabular}{|c|c|c|}
\hline Função & Trator & Motocultivador \\
\hline Acelerador & $\begin{array}{l}\text { Somente o acelerador de pedal possui } \\
\text { mola de retorno que reduz a rotação } \\
\text { ao se retirar o pé. }\end{array}$ & $\begin{array}{l}\text { O acelerador de mão não apresenta mola de } \\
\text { retorno e ao se retirar a mão este mantém a } \\
\text { última rotação aplicada, porém de forma } \\
\text { muito imprecisa. }\end{array}$ \\
\hline Embreagem & $\begin{array}{l}\text { Existe sensor que impede a ignição do } \\
\text { motor sem que o pedal seja acionado. }\end{array}$ & $\begin{array}{l}\text { Não possui sensor que impeça a ignição do } \\
\text { motor se esta estiver com marcha engatada. }\end{array}$ \\
\hline Freio & $\begin{array}{l}\text { O sistema de freio de operação possui } \\
\text { assistência hidráulica. Já no freio de } \\
\text { mão não há esse recurso. }\end{array}$ & $\begin{array}{l}\text { Por não possuir assistência mecânica o peso } \\
\text { da carga influi na força necessária para parar } \\
\text { o veículo, o que aumenta o risco de } \\
\text { acidentes em casos de desvio de obstáculos. }\end{array}$ \\
\hline $\begin{array}{l}\text { Troca de } \\
\text { Velocidade }\end{array}$ & $\begin{array}{l}\text { A caixa de velocidades possibilita a } \\
\text { troca em movimento, já a redução } \\
\text { exige que o veículo esteja parado. }\end{array}$ & $\begin{array}{l}\text { As trocas exigem veículo parado. O arranque } \\
\text { com marcha avançada pode representar } \\
\text { risco de perda de dirigibilidade e até a queda } \\
\text { do operador. }\end{array}$ \\
\hline Direção & $\begin{array}{l}\text { Não há nenhum sistema preventivo ou } \\
\text { que reduza os danos em caso de } \\
\text { erros. }\end{array}$ & $\begin{array}{l}\text { Não há nenhum sistema preventivo ou que } \\
\text { reduza os danos em caso de erros. }\end{array}$ \\
\hline Avaliação & Atende Parcialmente & Não Atende \\
\hline
\end{tabular}

Revista Produção Online, Florianópolis, SC, v.15, n. 3, p.830-858, jul./set. 2015. 


\subsubsection{Controle do usuário}

Quadro 9 - Análise do Princípio do Controle do Usuário para Trator e Motocultivador

\begin{tabular}{|c|c|c|}
\hline Função & Trator & Motocultivador \\
\hline Acelerador & $\begin{array}{l}\text { Os dois sistemas apresentam } \\
\text { sensibilidade que possibilita controle } \\
\text { sobre a rotação }(e \text { velocidade }) \text { da } \\
\text { máquina. }\end{array}$ & $\begin{array}{l}\text { O acelerador de mão está localizado na } \\
\text { extremidade da rabiça, sujeito à vibração } \\
\text { e exige que o operador retire a mão de } \\
\text { apoio para sua regulagem. Por isso } \\
\text { apresenta-se impreciso e de difícil } \\
\text { controle. }\end{array}$ \\
\hline Embreagem & $\begin{array}{l}\text { A embreagem acionada por pedal } \\
\text { possibilita bom controle do ponto de } \\
\text { tração, o que facilita as manobras em } \\
\text { campo. A embreagem por alavanca pode } \\
\text { ser acionada da posição sentada e } \\
\text { possibilita boa precisão no acionamento. }\end{array}$ & $\begin{array}{l}\text { A embreagem por manete apresenta a } \\
\text { limitação de ser acionada pela mão de } \\
\text { apoio, assim o operador perde } \\
\text { momentaneamente um importante ponto } \\
\text { de equilíbrio. O mesmo ocorre com a } \\
\text { embreagem geral (por alavanca) com o } \\
\text { agravante de exigir que o operador perca } \\
\text { o apoio lombar do acento. }\end{array}$ \\
\hline Freio & $\begin{array}{l}\text { O sistema de freio permite a frenagem } \\
\text { por roda, reduzindo assim o raio de giro e } \\
\text { melhorando a dirigibilidade. O freio de } \\
\text { mão possibilita controle sobre a máquina } \\
\text { estando esta parada. }\end{array}$ & $\begin{array}{l}\text { O freio no eixo motor exige que o } \\
\text { operador flexione a coluna, perdendo o } \\
\text { apoio lombar do acento. Já o freio da } \\
\text { carreta é acionado pelo pé e difícil de ser } \\
\text { acionado simultaneamente com o freio do } \\
\text { eixo motor. A frenagem isolada da carreta } \\
\text { ou do motocultivador pode ocasionar } \\
\text { acidentes por se tratar de estrutura } \\
\text { articulada. }\end{array}$ \\
\hline $\begin{array}{c}\text { Troca de } \\
\text { Velocidade }\end{array}$ & $\begin{array}{l}\text { As trocas em movimento permitem maior } \\
\text { controle sobre a qualidade e } \\
\text { produtividade da operação agrícola. }\end{array}$ & $\begin{array}{l}\text { As trocas que exigem a máquina parada } \\
\text { representam perdas na eficiência de } \\
\text { operação e maior risco de acidentes. }\end{array}$ \\
\hline Direção & $\begin{array}{l}\text { Permite o máximo esterçamento das } \\
\text { rodas sem a retirada das mãos do } \\
\text { volante. }\end{array}$ & $\begin{array}{l}\text { Para realizar o máximo esterçamento o } \\
\text { operador deve conduzir o pega-mão com } \\
\text { o braço do lado oposto ou até descer da } \\
\text { máquina e conduzi-la em pé. }\end{array}$ \\
\hline Avaliação & Atende & Não Atende \\
\hline
\end{tabular}

\subsubsection{Clareza visual}

Quadro 10 - Análise do Princípio da Clareza Visual para Trator e Motocultivador

\begin{tabular}{|c|l|l|}
\hline Função & \multicolumn{1}{|c|}{ Trator } & \multicolumn{1}{|c|}{ Motocultivador } \\
\hline Acelerador & $\begin{array}{l}\text { A rotação do motor é expressa de forma } \\
\text { clara e direta em um mostrador no painel } \\
\text { da máquina. }\end{array}$ & $\begin{array}{l}\text { Não há painel de mostradores ou } \\
\text { qualquer outra forma de indicar qual a } \\
\text { velocidade ou rotação da máquina. }\end{array}$ \\
\hline Embreagem & $\begin{array}{l}\text { Não há qualquer indicação para o sistema } \\
\text { por pedal e para a alavanca manual, } \\
\text { existe orientação esquemática de uso no } \\
\text { painel de instrumentos. }\end{array}$ & $\begin{array}{l}\text { Não há qualquer informação para a } \\
\text { embreagem por manetes. A embreagem } \\
\text { geral apresenta indicação por símbolo na } \\
\text { rabiça da máquina. }\end{array}$ \\
\hline Freio & $\begin{array}{l}\text { Não há qualquer indicação senão a } \\
\text { posição final dos elementos (alavanca e } \\
\text { pedal). }\end{array}$ & $\begin{array}{l}\text { Não há qualquer indicação senão posição } \\
\text { final dos elementos (alavanca e pedal). }\end{array}$ \\
\hline Velocidade & $\begin{array}{l}\text { Existe a indicação no manípulo das } \\
\text { alavancas das duas caixas. }\end{array}$ & $\begin{array}{l}\text { Existe indicação na base da alavanca de } \\
\text { troca mas para o sistema por polias não } \\
\text { há qualquer informação. }\end{array}$ \\
\hline Direção & $\begin{array}{l}\text { Não há qualquer indicação senão a } \\
\text { posição final do volante. }\end{array}$ & $\begin{array}{l}\text { Não há qualquer indicação senão a } \\
\text { posição final das rabiças. }\end{array}$ \\
\hline Avaliação & \multicolumn{1}{|c|}{ Atende } & \multicolumn{1}{c|}{ Atende Parcialmente } \\
\hline
\end{tabular}




\subsubsection{Priorização da funcionalidade}

Quadro 11 - Análise do Princípio da Funcionalidade para Trator e Motocultivador

\begin{tabular}{|c|c|c|}
\hline Função & Trator & Motocultivador \\
\hline Acelerador & $\begin{array}{l}\text { Ambos sistemas podem ser acionados na } \\
\text { posição sentado e sem retirar as mãos do } \\
\text { volante. O tacômetro ocupa posição de } \\
\text { destaque no centro do painel. }\end{array}$ & $\begin{array}{l}\text { Não há priorização da informação por não } \\
\text { haver velocímetro ou tacômetro } \\
\text { presentes. A função acelerador exige que } \\
\text { o operador retire a mão de apoio para sua } \\
\text { regulagem. }\end{array}$ \\
\hline Embreagem & $\begin{array}{l}\text { A embreagem acionada por pedal é } \\
\text { acionada pela perna esquerda com o } \\
\text { operador na posição sentada. A } \\
\text { embreagem por alavanca pode ser } \\
\text { acionada da posição sentada, com a } \\
\text { ressalva de estar à esquerda do } \\
\text { operador, dificultando a operação para } \\
\text { destros. }\end{array}$ & $\begin{array}{l}\text { A embreagem por manete apresenta a } \\
\text { limitação de ser acionada pela mão de } \\
\text { apoio embora esteja em local de } \\
\text { destaque na rabiça da máquina. Já a } \\
\text { embreagem geral (por alavanca) fica } \\
\text { afastada e exige que do operador flexão } \\
\text { de tronco e perca o apoio lombar do } \\
\text { acento. }\end{array}$ \\
\hline Freio & $\begin{array}{l}\text { O pedal de freio divide espaço com o } \\
\text { acelerador, além de ser dividido em dois } \\
\text { e unido por trava mecânica, mesmo } \\
\text { assim está em destaque na plataforma da } \\
\text { máquina. Já o freio de mão encontra-se à } \\
\text { esquerda do operador e em seu campo } \\
\text { visual. }\end{array}$ & $\begin{array}{l}\text { O freio no eixo motor exige que o } \\
\text { operador flexione a coluna para localizá- } \\
\text { lo e acioná-lo. Já o freio da carreta é } \\
\text { posicionado no campo visual do operador } \\
\text { e situado em distância adequada ao } \\
\text { alcance dos pés do operador. }\end{array}$ \\
\hline $\begin{array}{c}\text { Troca de } \\
\text { Velocidade }\end{array}$ & $\begin{array}{l}\text { As caixas estão em posição central e bem } \\
\text { visíveis, embora exijam a flexão do tronco } \\
\text { e perda do apoio lombar. }\end{array}$ & $\begin{array}{l}\text { A alavanca de troca está em região } \\
\text { central bem visível, mas exige a flexão do } \\
\text { tronco e perda do apoio lombar. Já a } \\
\text { redução exige o desligamento da } \\
\text { máquina e desmontagem } \\
\begin{array}{l}\text { componentes, operação complexa e } \\
\text { demorada. }\end{array}\end{array}$ \\
\hline Direção & $\begin{array}{l}\text { No desempenho da sua função principal o } \\
\text { trator necessita um redirecionamento } \\
\text { constante. O volante cumpre esse papel } \\
\text { por apresentar-se como elemento em } \\
\text { destaque no painel de instrumentos e ser } \\
\text { direto e preciso quando demandado. }\end{array}$ & $\begin{array}{l}\text { A rabiça do motocultivador é elemento de } \\
\text { direcionamento da máquina, mas não } \\
\text { atua de forma isolada. A condução e } \\
\text { desvio de obstáculos com a máquina } \\
\text { exige esforço proporcional à tração deste } \\
\text { com o piso. Há situações onde o } \\
\text { indivíduo, mesmo que aplique muita } \\
\text { força, não consegue fazer curvas sem a } \\
\text { utilização da embreagem. Esta retira a } \\
\text { tração da(s) roda(s) permitindo que o } \\
\text { operador movimente as rabiças e } \\
\text { redirecione a máquina. }\end{array}$ \\
\hline Avaliação & Atende Parcialmente & Não Atende \\
\hline
\end{tabular}




\subsection{9 - Transferência de tecnologia}

Quadro 12 - Análise do Princípio da Transferência de tecnologia para Trator e Motocultivador

\begin{tabular}{|c|c|c|}
\hline Função & Trator & Motocultivador \\
\hline Acelerador & $\begin{array}{l}\text { Ambos sistemas, pedal e alavanca de } \\
\text { rotação com largo emprego em máquinas } \\
\text { industriais e automóveis. }\end{array}$ & $\begin{array}{l}\text { O emprego do manete de aceleração por } \\
\text { cabo é muito difundido em máquinas } \\
\text { agrícolas motorizadas. Porém no } \\
\text { motocultivador a vibração constitui fator } \\
\text { que dificulta seu emprego preciso e } \\
\text { seguro. }\end{array}$ \\
\hline Embreagem & $\begin{array}{l}\text { A embreagem por pedal é muito } \\
\text { empregada na indústria automobilística e } \\
\text { em produtos onde o operador execute } \\
\text { sua atividade na posição sentada. A } \\
\text { embreagem por alavanca, por sua vez } \\
\text { tem emprego industrial há séculos, a } \\
\text { exemplos dos engenhos movidos à rodas } \\
\text { d'água. }\end{array}$ & $\begin{array}{l}\text { A embreagem por manete vem sendo } \\
\text { empregado em bicicletas e motocicletas } \\
\text { ao longo dos anos. Porém a posição que } \\
\text { encontra-se em relação ao braço faz com } \\
\text { que o punho sofra um desvio ulnar de até } \\
40^{\circ} \text {. A embreagem por alavanca vem do } \\
\text { emprego industrial. }\end{array}$ \\
\hline Freio & $\begin{array}{l}\text { O pedal de freio e a alavanca de freio de } \\
\text { mão são exemplos consolidados de } \\
\text { funcionalidade na indústria } \\
\text { automobilística. }\end{array}$ & $\begin{array}{l}\text { O freio no eixo motor exige que o } \\
\text { operador flexione a coluna para acioná-lo. } \\
\text { Em máquinas estáticas a concepção é } \\
\text { usual, porém em veículo, e sem devido } \\
\text { apoio corporal, há perdas em termos de } \\
\text { funcionalidade. Já o freio da carreta } \\
\text { segue a receita da indústria } \\
\text { automobilística. }\end{array}$ \\
\hline $\begin{array}{c}\text { Troca de } \\
\text { Velocidade }\end{array}$ & $\begin{array}{l}\text { As caixas são outro exemplo de } \\
\text { transferência de tecnologias dos } \\
\text { automóveis para as máquinas agrícolas } \\
\text { com sucesso. }\end{array}$ & $\begin{array}{l}\text { A alavanca de troca está } \\
\text { consonância as em } \\
\text { automóveis. Já a troca por polias tem seu } \\
\text { emprego restrito a maquinas de produção } \\
\text { industrial, onde as trocas de velocidade } \\
\text { não são tão constantes como em } \\
\text { veículos. }\end{array}$ \\
\hline Direção & $\begin{array}{l}\text { O volante é um dos componentes mais } \\
\text { difundidos e presente há décadas na } \\
\text { indústria automobilística. Sua } \\
\text { transferência para outros produtos } \\
\text { automotores se deu de maneira natural. }\end{array}$ & $\begin{array}{l}\text { O sistema de rabiças remonta à época da } \\
\text { tração animal, quando este puxava um } \\
\text { implemento agrícola conduzido por } \\
\text { rédeas à distância. O termo "rabo do } \\
\text { arado" está na origem do nome "trator de } \\
\text { rabiças". }\end{array}$ \\
\hline Avaliação & Atende & Atende Parcialmente \\
\hline
\end{tabular}

\subsubsection{Evidência}

Quadro 13 - Análise do Princípio da Evidência para Trator e Motocultivador

\begin{tabular}{|c|c|c|}
\hline Função & Trator & Motocultivador \\
\hline Acelerador & $\begin{array}{l}\text { A interpretação do funcionamento do } \\
\text { pedal de aceleração é mais rápida e } \\
\text { assertiva do que a da alavanca, mas } \\
\text { ambos comandos apresentam-se de } \\
\text { forma explícita. }\end{array}$ & $\begin{array}{l}\text { Embora menos empregado, o sistema de } \\
\text { aceleração por manete e cabo também é } \\
\text { intuitivo e explícito. }\end{array}$ \\
\hline Embreagem & $\begin{array}{l}\text { O funcionamento do pedal de aceleração } \\
\text { é mais explícito do que o da alavanca, } \\
\text { mas ambos apresentam-se de forma } \\
\text { clara e evidente. }\end{array}$ & $\begin{array}{l}\text { A embreagem por manete não apresenta- } \\
\text { se de forma intuitiva e explícita. Quanto } \\
\text { ao modelo por alavanca a evidência } \\
\text { quanto ao seu funcionamento é mais } \\
\text { direta. }\end{array}$ \\
\hline
\end{tabular}


Quadro 13 - Análise do Princípio da Evidência para Trator e Motocultivador

\begin{tabular}{|c|c|c|}
\hline Função & Trator & Motocultivador \\
\hline Freio & $\begin{array}{l}\text { O pedal de freio e o freio de mão seguem } \\
\text { os princípios dos estereótipos populares e } \\
\text { por serem largamente difundidos são } \\
\text { identificados rapidamente. }\end{array}$ & $\begin{array}{l}\text { Ambos sistemas são evidentes, embora } \\
\text { o freio da carreta seja mais explícito que } \\
\text { o por alavanca. }\end{array}$ \\
\hline $\begin{array}{c}\text { Troca de } \\
\text { Velocidade }\end{array}$ & $\begin{array}{l}\text { A caixa principal é mais evidente que a } \\
\text { caixa de redução por esta necessitar } \\
\text { pressão sobre a alavanca além da } \\
\text { condução até a nova posição. Ambas têm } \\
\text { funcionamento evidente. }\end{array}$ & $\begin{array}{l}\text { A alavanca de troca atende aos } \\
\text { requisitos de evidência por ser explícita e } \\
\text { de fácil interpretação, o que não ocorre } \\
\text { com o sistema de troca por polias. }\end{array}$ \\
\hline Direção & $\begin{array}{l}\text { O volante, por ser um dos componentes } \\
\text { mais difundidos na indústria } \\
\text { automobilística, tem sua funcionalidade } \\
\text { quase que intuitiva. }\end{array}$ & $\begin{array}{l}\text { O sistema de rabiças associado com a } \\
\text { embreagem se torna pouco evidente e } \\
\text { exige do operador experiência e cuidados } \\
\text { especiais. }\end{array}$ \\
\hline Avaliação & Atende & Atende Parcialmente \\
\hline
\end{tabular}

Quadro 14 - Resumo das avaliações pela ISO 9241-11 (1998) e os princípios de Jordan (1998) utilizando o modelo U-DC) (MERINO et al., 2012)

\begin{tabular}{|l|c|c|}
\hline \multicolumn{1}{|c|}{ Item } & Trator & Motocultivador \\
\hline Eficiência & Atende & Atende \\
\hline Eficácia & Atende & Atende Parcialmente \\
\hline Satisfação & Atende & Atende \\
\hline Consistência & Atende & Não atende \\
\hline Compatibilidade & Atende & Não Atende \\
\hline Capacidade & Atende & Não Atende \\
\hline Retro-Alimentação & Atende & Não Atende \\
\hline Prevenção de erro & Atende Parcialmente & Não Atende \\
\hline Controle do usuário & Atende & Não Atende \\
\hline Clareza visual & Atende & Atende Parcialmente \\
\hline $\begin{array}{l}\text { Priorização da } \\
\text { funcionalidade }\end{array}$ & Atende Parcialmente & Não Atende \\
\hline $\begin{array}{l}\text { Transferência de } \\
\text { tecnologia }\end{array}$ & Atende & Atende Parcialmente \\
\hline Evidência & Atende & Atende Parcialmente \\
\hline
\end{tabular}

O resultado gráfico das fases II e III pode ser visualizado na figura a seguir.

Figura 4 - Resultado Gráfico das fases II e III para trator (e) e motocultivador (d)

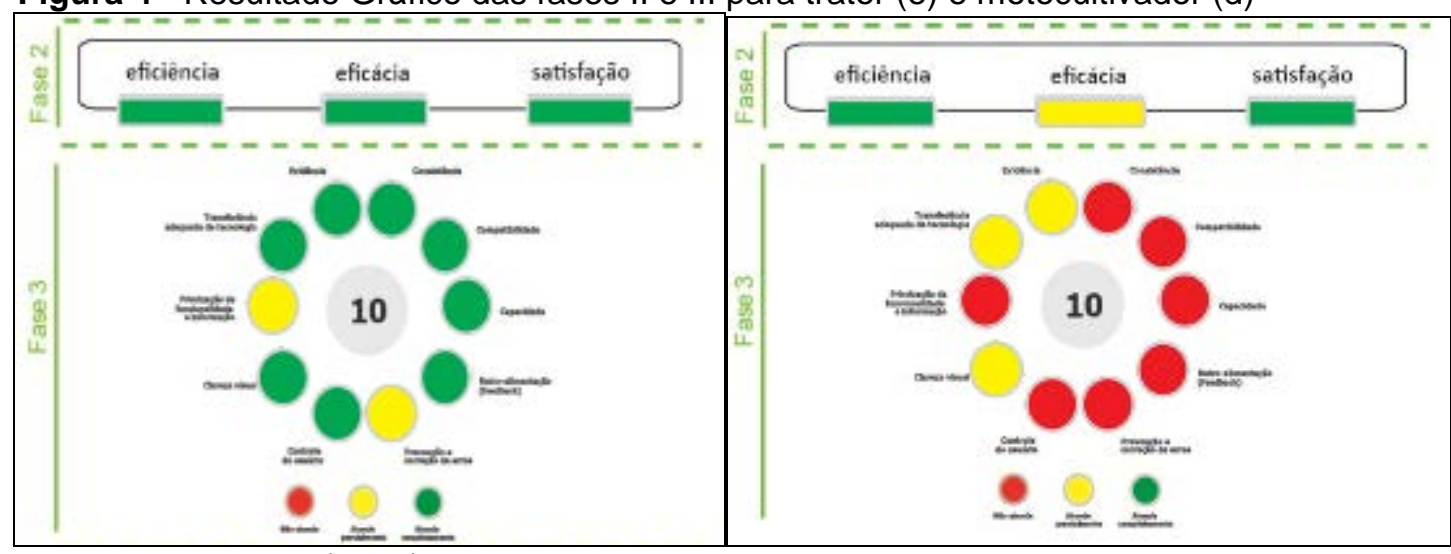

Fonte: Merino et al. (2012) 
O resultado da avaliação de usabilidade em termos de ISO 9241-11 (1998) apresentada na fase II apontou níveis similares entre o trator e o motocultivador. A eficácia do motocultivador foi o único ponto que o diferenciou do trator. Tal fato pode ser justificado pela baixa velocidade na execução das operações agrícolas em decorrência de sua pequena dimensão e potência além de possuir apenas duas rodas.

A fase III apresentou maior diferenciação. O gráfico a seguir apresenta a quantidade de princípios atendidos, atendidos parcialmente ou não atendidos pelas duas máquinas avaliadas para esta fase.

Graf. 5 - Comparação entre as máquinas com base nos dez princípios de Jordan (1998)

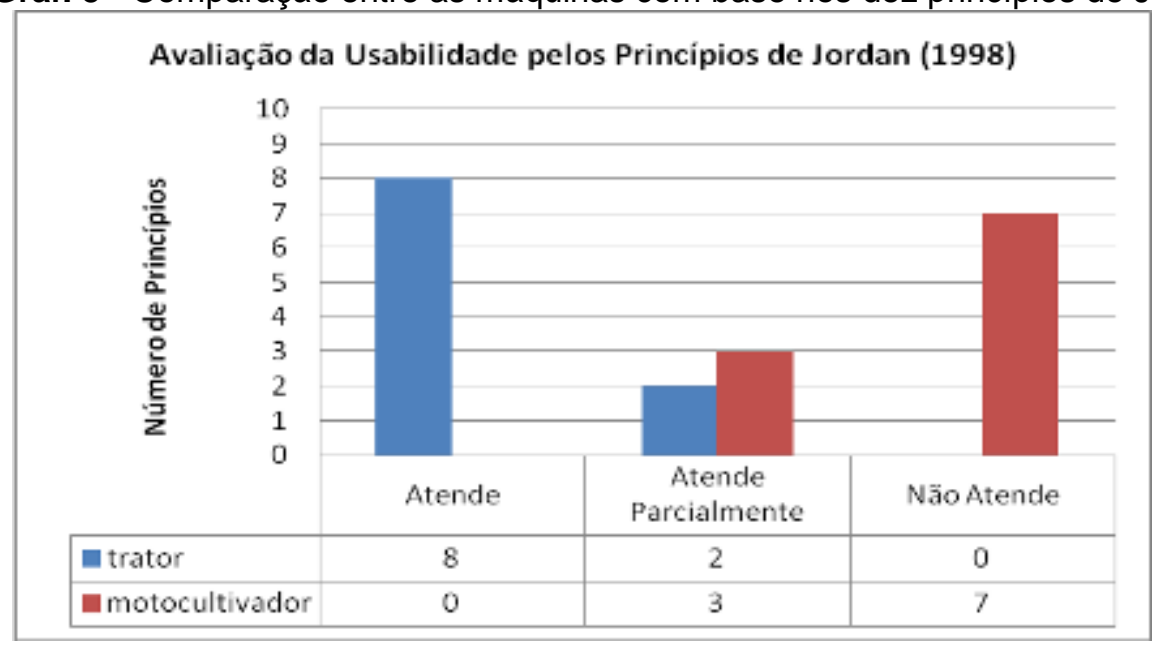

Pelo ponto de vista dos dez princípios de Jordan (1998) as diferenças são mais visíveis. Enquanto o trator atende a $80 \%$ dos princípios, o motocultivador não atende em $70 \%$.

Ressalta-se que os dois princípios de menor nota para o trator, que foram: priorização da funcionalidade e prevenção de erros, recebendo avaliação "Atende Parcialmente", também receberam avaliação negativa no motocultivador, avaliados com "Não Atende". Isto remete a deficiência pela ausência de informações de "como executar" determinada operação ou se esta "foi ou não executada". Existe ainda, no setor de máquinas agrícolas de pequeno porte, uma resistência a novas tecnologias que poderiam facilitar a interação com o usuário, tal como a eletrônica. $\mathrm{O}$ fato de a robustez ser fator preponderante na escolha da máquina para o comprador desobriga o fabricante de investir em tecnologias. Exemplo disso é que o 
motocultivador não possui painel de instrumentos, nem mesmo como opcional no momento da compra.

Os resultados das fases anteriores e que compõem a fase IV do modelo serão discutidos a seguir em comparação com os obtidos no teste de usabilidade.

\subsection{Resultados do teste de usabilidade}

\subsubsection{Questionário}

O resultado do questionário demonstrou que a maioria dos entrevistados estava tendo contato pela primeira vez com o motocultivador, ou seja, 36 dos 53 entrevistados.

Gráf. 6 - Níveis de experiência dos usuários com o motocultivador

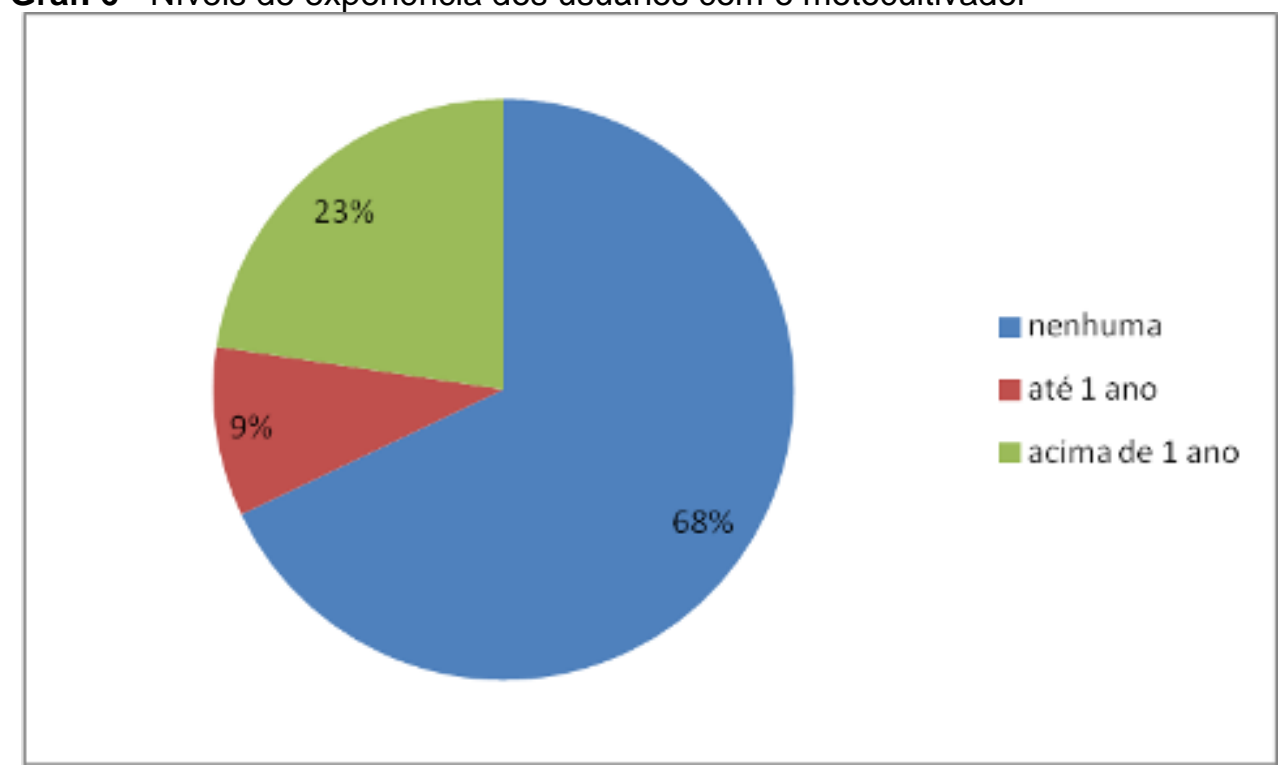

Embora a maioria dos entrevistados não tivesse contato anterior, 23 dos 53 jovens possuíam motocultivador em sua propriedade agrícola familiar. 
Gráfico 7 - Níveis de experiência dos usuários com o trator

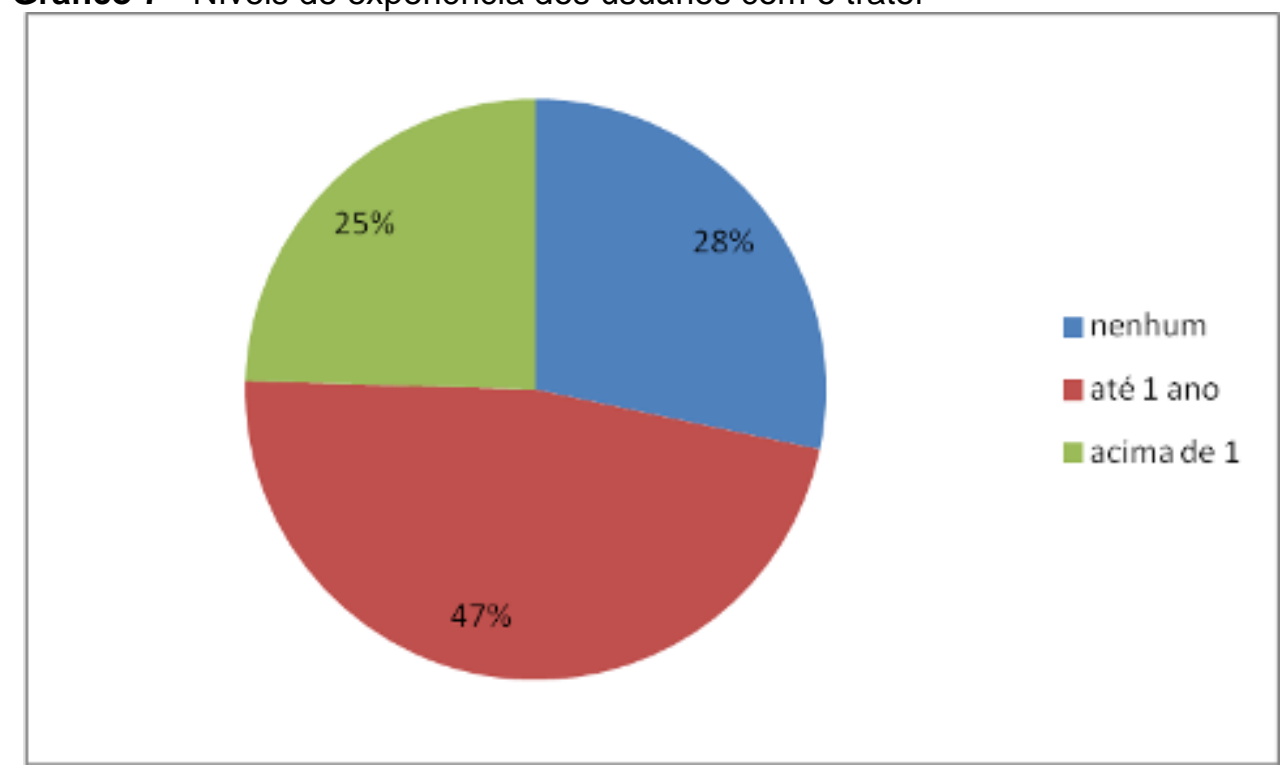

O trator estava presente nas propriedades de 22 entrevistados.

Esses números reforçam a existência da agricultura familiar bem desenvolvida no estado e que o motocultivador está presente em grande parte das propriedades, em número próximo ao de tratores.

A constatação de que $72 \%$ dos jovens possuíam experiência na operação de tratores e apenas 32\% possuíam experiência em motocultivadores e considerando que havia mais motocultivadores (23) que tratores (22) nas propriedades dos entrevistados pode ser explicado pelo receio dos pais em ensinarem os filhos a operar motocultivadores, pelo alto risco de acidentes que este oferece.

A percepção do usuário quando questionado quanto à segurança, demonstrou que $98,1 \%$ considerava o motocultivador menos seguro que o trator.

Gráfico 8 - Percepção do usuário quanto à segurança na operação da máquina

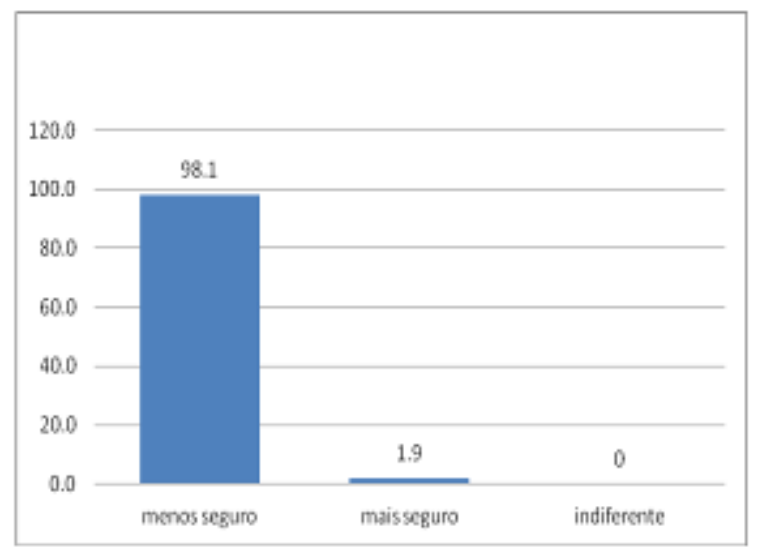




\subsubsection{Avaliação do erro}

O teste demonstrou que, no acionamento dos comandos do motocultivador, 49,1\% dos usuários não conseguiram desviar o obstáculo representado pela lâmpada colorida ligada na extremidade do quadro. Para o trator esse erro foi de $5,7 \%$.

Gráfico 9 - Porcentagem de erro no acionamento do comando para motocultivador e trator

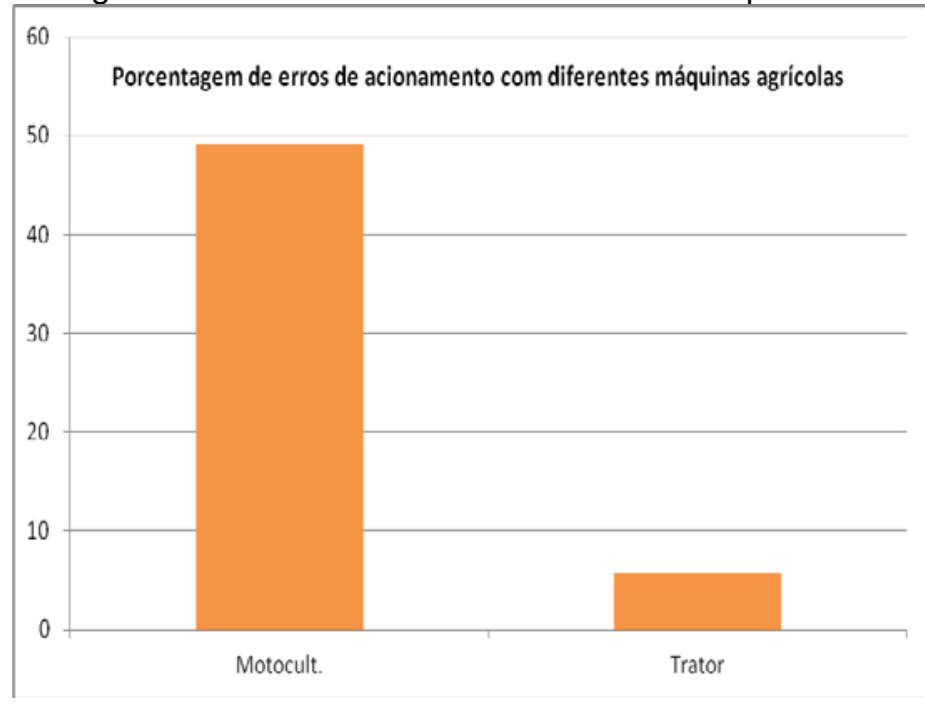

Um dos motivos para o motocultivador apresentar tal índice pode estar na maior exigência de carga mental, pois o operador deve considerar não somente a posição do obstáculo (direita ou esquerda), mas também a condição de aclive ou declive do terreno, o que não é necessário no caso do trator.

As experiências com outros veículos, como automóveis, pode ter influência na melhor resposta ao estímulo para o trator.

A análise detalhada por níveis demonstrou proporcionalidade entre índice de erros e experiência. O melhor resultado para níveis de experiência maiores demonstra que o contato anterior com a máquina pode reduzir os erros de acionamento.

Tabela 1 - Distribuição do erro por nível
\begin{tabular}{|l|c|c|}
\hline \multicolumn{1}{|c|}{ Nível de experiência } & Trator & Motocultivador \\
\hline 1 - nenhuma & $20,0 \%$ & $52,8 \%$ \\
\hline 2 - até 1 ano & $0 \%$ & $20,0 \%$ \\
\hline 3 - mais de 1 ano & $0 \%$ & $50,0 \%$ \\
\hline
\end{tabular}


A percepção de insegurança, declarada no questionário, foi confirmada pelos índices de erros de acionamento do sistema de direção. Os usuários perceberam que o motocultivador era mais inseguro que o trator antes do teste e após houve a confirmação através dos erros de acionamento. Pode-se concluir que a complexidade na operação do motocultivador, para estes usuários, foi um fator que contribuiu para classificar a máquina como insegura em relação ao trator.

\section{CONCLUSÕES}

O erro de acionamento abordado nesse estudo pode representar uma das principais causas de acidentes com máquinas agrícolas.

O emprego do modelo U-D@ se mostrou apropriado para análise de produtos da área agrícola e contribuiu para se atingir os objetivos desse trabalho. Já o teste de usabilidade possibilitou, de forma rápida, a obtenção de dados que contribuíram para a avaliação dos dois produtos.

Os resultados, tanto pela avaliação utilizando o modelo U-D@ (MERINO et al., 2012) como no teste de usabilidade demonstraram a fragilidade do projeto do motocultivador, evidenciando a necessidade de melhorias nos aspectos funcionais e de segurança.

A pesquisa apontou questões importantes à ergonomia que constituem contribuições no campo social: com a possibilidade de redução do número de mortos e feridos no trabalho agrícola; econômica: pela possibilidade de redução dos custos de afastamentos e indenizações trabalhistas; bem como tecnológicas: por oportunizar melhorias em projetos de produtos agrícolas.

Sugere-se, para trabalhos futuros, a avaliação de usabilidade de equipamentos instalados em motocultivadores, como as carretas tracionadas com direção hidráulica, que atualmente são comercializados com a prerrogativa de melhorarem o desempenho e a segurança desta máquina.

\section{REFERÊNCIAS}

DEBIASI, H.; SCHLOSSER, J.F; WILLES, J.A. Acidentes de trabalho envolvendo conjuntos tratorizados em propriedades rurais do Rio Grande do Sul, Brasil. Ciência

Rural, v.34, n.3, Santa Maria, maio/jun. 2004. Disponível em

http://www.scielo.br/pdf/cr/v34n3/a19v34n3.pdf . Acesso em 22 jun. 2013.

Revista Produção Online, Florianópolis, SC, v.15, n. 3, p.830-858, jul./set. 2015. 
DOUGHERTY, E.M. Is human failure a stochastic process? Reliability Engineering and System Safety, n. 55, p. 209-215, 1997. http://dx.doi.org/10.1016/S0951-8320(96)00122-6

FERREIRA, A.L.R.; FERREIRA JUNIOR, L.D. ; ALVES, F.J.C.. Seleção de pontos de verificação do instrumento ergonomic checkpoints in agriculture para o processo de colheita mecanizada da cana-de-açúcar. Revista Produção Online, v. 14, p. 1537-1557, 2014. DOI: http://dx.doi.org/10.14488/1676-1901.v14i4.1724

GIL, A. C. Como elaborar projetos de pesquisa. 4. ed. São Paulo: Atlas, 2002.

IBGE. Censo Agropecuário 2006: Resultado Preliminar. Rio de Janeiro: IBGE, 2007, 141 p.

IBGE. Censo Agropecuário 1996. Rio de Janeiro: IBGE, 1996, 122 p.

ISO (1998). ISO 9241-11: Ergonomic requirements for office work with visual display terminals (VDTs). Part 11 Guidelines for specifying and measuring usability. Gènève: International Organisation for Standardisation.

IIDA, I. Ergonomia, projeto e produção. São Paulo: Edgard Blucher Ltda, 2005.

JORDAN, P.W. An Introduction to Usability. Lodon: Taylor \& Francis.1998.

JUNIOR, W.P.C.; SELL, I. Produto como causador de acidentes. Produção Online, Universidade Federal de Santa Catarina Florianópolis - SC - Brasil - ISSN 1676 - 1901 / v.4, n.2, p.1 - 19, maio de 2003. Disponível em

http://producaoonline.org.br/rpo/article/view/305.Acesso em 13 jul. 2013.

http://dx.doi.org/10.14488/1676-1901.v4i2.305

MÁRQUEZ, Luiz. Tractores Agrícolas: tecnología y Utilización. Editora B\&H. Madrid, 2011.

MENEGAS, M. T.; DALLMEYER, A. U.; SCHOLOSSER, F. Apreciação ergonômica da cabina de tratores agrícolas - visibilidade. Produção Online, Universidade Federal de Santa Catarina Florianópolis - SC - Brasil - ISSN 1676 - 1901 / v.6, n.1, p.1 - 14, jan./mar. 2006. http://dx.doi.org/10.14488/1676-1901.v6i1.82

MERINO, Giselle Schmidt Alves Díaz et al. Usability in Product Design - The importance and need for systemic assessment models in product development - Usa-Design Model (UD). Work, Usa, v. 41, n. 1, p.1045-1052, fev. 2012. http://dx.doi.org/10.3233/WOR-20121011-1045

ODORIZZI, W.; MASIERO, F.C.; VEIGA, R.K. Acidentes com máquinas agrícolas: pesquisa realizada com alunos do IFC Câmpus Rio do Sul. In: VI MICTI. Anais... ISSN 2316-7165. Outubro de 2013.

OCDE. Code 10. Disponível em http://www.oecd.org/tad/code/Code\%2010\%20\%20Final.pdf. Acesso em 09 de set. de 2013.

SCHLOSSER, J.F.; DEBIASI, H.; PARCIANELLO G.; RAMBO L. Caracterização dos acidentes com tratores agrícolas. Ciência Rural, v.32, n.6, Santa Maria, nov./dez. 2002. Disponível em http://www.scielo.br/scielo.php?pid=S0103-

84782002000600010\&script=sci_arttext. Acesso em: 21 mai. 2013. http://dx.doi.org/10.1590/S0103-84782002000600010 
VEIGA, R.K.; GONTIJO, L.A.; MASIERO, F.C. ODORIZZI, W.; VENTURI, J. Erros em acionamento de comandos: comparação entre dois modelos de tratores agrícolas. In: Encontro Nacional de Engenharia de Produção, 2013, Salvador. Anais... São Paulo, 2013.

VEIGA, R. K. ; GONTIJO, L. A. ; MASIERO, F. C. ; VENTURI, J. ; ODORIZZI, W.. Emprego da análise ergonômica do trabalho em atividade com máquina agrícola motorizada. Exacta - EP, São Paulo, v. 12, n. 1, p. 123-123, 2014.

http://dx.doi.org/10.5585/exactaep.v12n1.4712

VIEIRA, S. Como escrever uma tese. 6 ed. São Paulo: Editora Atlas, 2008.

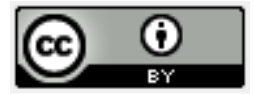

Artigo recebido em 06/12/2013 e aceito para publicação em 29/06/2015

DOI: http://dx.doi.org/ 10.14488/1676-1901.v15i3.1712 